\title{
Disruption and Legitimacy: Big Data in Society
}

\author{
Carlos Ferreira $^{1}$ (D) $\cdot$ Alessandro Merendino ${ }^{1} \cdot$ Maureen Meadows $^{1}$ \\ Accepted: 7 June 2021 \\ (C) The Author(s), under exclusive licence to Springer Science+Business Media, LLC, part of Springer Nature 2021
}

\begin{abstract}
The growing availability of data and the emergence of business analytics ecosystems offer possibilities for companies developing innovative business models. However, the disruptive impact of these business models on society is not always judged favourably. This paper explores the growing tensions in the relationship between disruptive Big Data companies and society through the lens of legitimacy - a judgement about the fit and propriety of an entity, such as a company, to society. The study is based on four instrumental cases where Big Data organisations were faced with challenges to their legitimacy. The findings elaborate how digital transformations require companies to understand and manage how much to disrupt and how much to conform to social norms and values. Big Data businesses face a dynamic and paradoxical tension between the potential costs and benefits of their disruptive business models. The topic of legitimacy management is also addressed, drawing out implications for practice.
\end{abstract}

Keywords Big data $\cdot$ Legitimacy $\cdot$ Disruption

\section{The Promise and Perils of Big Data}

The growing availability of data and the development of business analytics ecosystems offer new possibilities for companies willing to adopt innovative approaches (Huang et al., 2017; Pappas et al., 2018; Tan, 2018; Zhan et al., 2017). From a business strategy standpoint, this has been translated into innovative forms of doing business, such as the sharing economy (Hamari et al., 2016) or the set of phenomena described as Industry 4.0 (Lasi et al., 2014). Entirely new business models have emerged from Big Data and the analytics ecosystems which make use of it. It is now possible to speak about a digital transformation of societies through Big Data, as summarised in the so-called Digital Transformation and Sustainability (DTS) model (Pappas et al., 2018). However, if Big Data are producing business and societal transformation, there is also evidence that those changes can have negative consequences. Emerging business models which harness

Carlos Ferreira

carlos.ferreira@coventry.ac.uk

Alessandro Merendino

alessandro.merendino@ coventry.ac.uk

Maureen Meadows

maureen.meadows@coventry.ac.uk

1 Centre for Business in Society (CBiS), Coventry University, Priory Street, Coventry CV1 5FB, UK
Big Data can often be disruptive to entire sectors, industries and even the social structures in which the disruptor operates (Millar et al., 2018). Such instances of disruption, while often delivering cost savings and value to consumers, can have negative consequences. These include - among others - job losses, increased inequality and reduced social cohesion (O’Neil, 2016), threats to individual citizens' privacy (Degli Esposti, 2014; Zuboff, 2015) and the disruption of democratic institutions (Lytvynenko, 2020; Sherr, 2018). As a result, the role and place of Big Data companies, and the desirability of their business models, are increasingly being discussed by societal actors. This paper explores the growing tensions in the relationship between disruptive Big Data companies and society.

While existing literature, such as the DTS model (Pappas et al., 2018), explains how Big Data can disrupt or improve business models, the impact of those transformations on society, and how society reacts to disruption, remain undertheorised. To address this issue, this paper adopts legitimacy as a theoretical lens (Deephouse et al., 2017). Legitimacy is a core resource for any organisation, making it seem natural and meaningful, and ultimately conferring the organisation with social, as well as economic, fitness (DiMaggio \& Powell, 1983; Suchman, 1995). However, companies employing Big Data business models often operate in a paradigm whereby being disruptive is a condition for success (Bean, 2018; Newman, 2014). The disruption they cause can have negative impacts on society, opening the organisation to adverse 
judgements and, subsequently, loss of legitimacy (Ferreira et al., 2019).

The relationships between Big Data organisations and society are under-researched, as well as under-developed from a business management point of view. In the light of these lacunae, this paper addresses two research questions. First, in what ways does the disruptive innovation caused by Big Data business models affect Big Data organisations' legitimacy? And second, how can Big Data organisations manage the challenges to their legitimacy? These research questions are addressed by adopting a multiple instrumental case study design (Stake, 1995), focusing on companies whose disruptive Big Data-enabled business models have provoked controversy and subsequent loss of legitimacy. The paper makes two conceptual contributions. First, it elaborates a model that identifies the challenges faced by companies employing these business models. This model - the legitimacy-disruption paradox - stipulates that Big Data companies need to identify a workable trade-off between promoting disruptive changes and fitting with existing social norms and values. Second, the paper extends the DTS model (Pappas et al., 2018), in the light of the legitimacy-disruption paradox, by explicitly including social dimensions and the management of the organisations' legitimacy.

The paper is organised as follows. Section 2 reviews the literature on Big Data and legitimacy. Section 3 details the research methodology and introduces the four case studies. Section 4 presents the findings and Section 5 discusses them through the legitimacy and Big Data theoretical lenses adopted. The paper concludes with contributions to theory and practice, and avenues for future research.

\section{Big Data and Society}

\subsection{Big Data Business Models as Disruptive Innovation}

Big Data refer to large datasets of diverse digital data inputs requiring powerful computational technologies to be processed (George et al., 2014). Five dimensions, referred to as the 5 Vs (Erevelles et al., 2016), help define Big Data: Volume - a large amount of data generated per unit of time; Velocity the speed at which data is generated (Fosso Wamba et al., 2015); Veracity - the trustworthiness (M. Gupta \& George, 2016) and quality of data (Janssen et al., 2017); Variety - the different formats of data, such as emails, CCTV videos, audios, texts and financial transactions (Blazquez \& Domenech, 2018); and Value - the added value that data provide to organisations (Opresnik \& Taisch, 2015). Data need to evidence at least one of the $5 \mathrm{Vs}$ in order to be classified as Big Data. A Big Data company is an organisation whose business model is based on the regular use of Big Data to add value to their activities.
Big Data business models have been characterised as a form of disruptive innovation (Bean, 2018; OECD, 2015; Prescott, 2016; van den Broek \& van Veenstra, 2018; Zillner et al., 2016). Disruptive innovations were traditionally characterised as strategic actions taken by companies, which gave them an advantage over competitors in the same market. In this paradigm, the focus of the analysis is the strategy of the disruptor companies; the extent of the disruption is, in general, confined to the market segment in which the disruptor and disrupted operate (Christensen, 1997; Denning, 2016). However, recent scholarship takes a broader view of the extent to which disruption can have an impact beyond the ranking of competitors in a market. Researchers note that the discontinuity provoked by disruptive innovations makes existing business models inviable, and can reverberate across the industry segment, the industry structure and even the social structure in which the disruptor is operating (Millar et al., 2018). Building on this, Kilkki et al. (2018) take a systemic view of the social field on which disruption occurs. In their formulation, a system suffers disruption when a significant portion of agents in that system must reformulate their strategies in order to survive an innovation. The authors classify agents in the disrupted system ranging through scientific communities, $R \& D$ units, firms, industries, consumers and society/ authorities. All these agents may be disrupted by innovations, and therefore be forced to react (Kilkki et al., 2018). To sum up, disruptive innovation has the potential to impact well beyond the firm or industry segment in which it occurs, and requires those affected to adapt in order to continue to operate.

The possibility that disruptive innovations can affect a wider group of agents raises the question of whether those agents perceive it as attractive ("good") or adverse ("bad"). In his initial formulation of the term, Christensen (1997) implicitly saw disruption as a net positive: the disruptive technology was assumed to provide the disruptor with a competitive advantage and consumers with added value. In this mod$\mathrm{el}$, the disruptive technology is only a net negative for the incumbent competitor. This position is consistent with the view of innovation as creative destruction (Schumpeter, 1942), whereby human and social progress require the elimination of less competitive firms. However, expanding the view to take on potential impacts over other parts of the system, the disruptive impact of Big Data becomes more complex, as shown by the growing debate about the opportunities and challenges of Big Data (Chen \& Zhang, 2014; Popovič et al., 2018; Stahl et al., 2014; Wilson et al., 2017; Zadeh et al., 2019). The opportunities include rapid yet accurate strategic decision-making (Merendino et al., 2018), value creation (Huang et al., 2017), flexibility of resource allocation (A. Gupta et al., 2018), minimisation of costs, customer retention and tackling fraud. On the other hand, Big Data challenges include the lack of skilled workers and other resources (Bharati \& Chaudhury, 2019), job losses, increased inequality, 
reduced social cohesion (O’Neil, 2016), challenging collaborations with stakeholders (Braganza et al., 2017) and the possible loss of organisational legitimacy (Ferreira et al., 2019; Fredriksson, 2018). In this debate, Pappas et al. (2018) theorise the DTS model in the context of Big Data ecosystems. In the DTS model, Big Data actors - 'academia', 'individuals/ entrepreneurs', 'industry/private organisations', 'civil society' and 'government/public organisations' - can affect value creation and produce business and societal change. These actors are expected to collaboratively develop Big Data capabilities (George et al., 2014) in order to achieve digital transformation and sustainable societal changes. Nevertheless, the model appears to presuppose that said transformation could be easily and readily accepted by societies. However, there is evidence that societies can judge the business models of Big Data companies as a net negative (Ferreira et al., 2019).

\subsection{Big Data Companies in Society: The Concept of Legitimacy}

Legitimacy consists of a judgement about the desirability, propriety or appropriateness of the actions of an entity - such as a company - vis-à-vis prevalent values and meanings in society (Deephouse et al., 2017). The level of analysis of legitimacy is holistic: according to Deegan (2002), the theory is concerned with the relationship between the organisation and society as a whole, and does not consider individuals' unique perspectives and evaluations of an organisation (Deegan, 2002). ${ }^{1}$ Given that all organisations exist within societies, from which they must obtain resources (human resources, capital, access to markets), legitimacy theory implies the existence of a social contract, which defines whether the organisation's actions conform to social expectations (Brown \& Deegan, 1998; Fernando \& Lawrence, 2014). To be legitimate, a business must be well aligned with the norms, rules, values and definitions prevalent in a society (Deephouse et al., 2017; Scott, 2014). If it remains so, the business will maintain its social license to operate; breaking the social contract can result in this license being revoked (Brown \& Deegan, 1998).

In general, most stakeholders will only engage with businesses seen as legitimate (Deephouse et al., 2017; Lillqvist et al., 2017; Suddaby et al., 2017). Being perceived as legitimate gives an organisation a 'taken-for-granted' status; the organisation is likely to be perceived as an objective and natural reality, which means its existence is not in question - the organisation becomes a fact of life (Tost, 2011). In contrast, when an organisation operates in a way that runs against

\footnotetext{
1 Throughout this paper, the authors follow an institutional approach to legitimacy (e.g., Deephouse et al., 2017), which is not concerned with individuals' perceptions. An alternative model of legitimacy, which does consider individual judgements, is found in the discipline of social psychology. This latter model is not used in the present research. For a detailed discussion of the commonalities and differences between the two models, see Tost (2011).
}

society's values, stakeholders can judge that it is outright illegitimate and oppose its existence or demand radical reform. This is the situation faced by companies forced out of business. These two extremes of legitimacy evaluation of an organisation (taken-for-granted and opposed to its existence in its current form) are referred to as Accepted and Illegitimate. It is also possible to identify at least two intermediate levels of legitimacy: Proper - when the organisation is seen as legitimate, but subject to external audit - and Debated. In the latter case, the organisation's actions and fundamental values are actively challenged and questioned in the social system (Deephouse et al., 2017).

Legitimacy is a society-wide dimension, but it is conferred by specific audiences or evaluators (Bitektine, 2011; Bitektine $\&$ Haack, 2015). These evaluators observe and judge an organisation's actions, and generalise that evaluation into a broader consensus about the appropriateness and fit of the organisation (Deephouse et al., 2017). Amongst the key evaluators are the state, the justice system and the media. The latter, in particular, is often a key legitimacy evaluator. Research has shown that media reports about companies' actions lead companies to change their operations, in order to maintain or improve legitimacy (Brown \& Deegan, 1998). These judgements are not exclusively fact-based but can also be the result of relatively superficial perceptions about the fit of a business to existing moral norms, beliefs and values (Haack et al., 2014). Judgements of what constitutes appropriate action in a given context are based on distinctive dimensions, sometimes also described as pillars of legitimacy (Lillqvist et al., 2017).

Deephouse et al. (2017) suggest four distinct dimensions of legitimacy. The first dimension is regulatory legitimacy, associated with a perception of whether the organisation follows existing rules. This establishes a 'baseline' legitimacy, ascertaining that the organisation is legal, and that engagement with it is unlikely to result in penalties. The second dimension is pragmatic legitimacy. This requires an organisation to demonstrate that it can deliver on claims associated with the measurable performance of its products or services. A company whose products systematically fail to perform as described is likely to be seen as illegitimate. The third dimension, moral legitimacy, relates to values. To achieve this level of legitimacy, an organisation must demonstrate that it follows collectively valued purposes, values and goals. Illegitimacy, in this case, relates to situations where the actions of an organisation are legal, but seen as immoral. The final dimension, known as cultural-cognitive legitimacy, involves demonstrating the fit between an organisation and socially shared meaning systems. These meaning systems are pervasive, and consist of takenfor-granted and shared understandings. Cultural-cognitive legitimacy is a feature of institutions which are entirely embedded in their cultural environment; the simple fact that their existence is questioned suggests that their legitimacy is under 
threat (Cashmore \& Wejs, 2014). Tost (2011) argues that cultural-cognitive legitimacy is a feature of taken-forgrantedness in the judgement process; in fact, it consists of an absence of substantive content in the legitimacy judgement. An organisation achieves cultural-cognitive legitimacy in the absence of questions or challenges to its existence.

Each of these four dimensions of legitimacy plays an important role in stabilising organisations. They promote the use of practices that are formally authorised, deliver the promised benefits, are acceptable on normative grounds, and draw on social understandings. This is especially important for organisations which are promoting innovative products or services: once those organisations become legitimate - once they become accepted social facts - individuals are more likely to adopt the products and services they offer (Gollnhofer, 2017). For this reason, legitimacy management and recovery has become a field of interest to institutions in the public eye. Suddaby et al. (2017) suggest that organisations can adopt three main strategies to recover their legitimacy: conforming, decoupling and performing. Organisations choosing a strategy of conforming will adopt characteristics, practices and norms imposed by regulations, standards or norms (e.g., DiMaggio \& Powell, 1983). Organisations adopting a strategy of decoupling might superficially conform to social norms, in order to appear legitimate and buffer and protect their core economic or technical activities. Organisations tend to adopt this strategy when they seek to maintain a degree of fit within the ecosystem where they operate (Suddaby et al., 2017). The performing strategy is usually adopted by organisations which set out to demonstrate their technical superiority over the alternatives. Institutions whose legitimacy is challenged can apply a combination of those strategies in order to manage their legitimacy (Schembera \& Scherer, 2017).

The section above demonstrates the fit of legitimacy theory for the analysis of how societies evaluate the impact of Big Data companies. First, the fit is reflected by the level of analysis: this paper takes an interest in the effect of disruption caused by Big Data business models in the societies in which these organisations operate. Legitimacy theory applies to the relationship between the organisation and society as a whole, not individual perspectives. Second, there is precedent: legitimacy theory has been used to research how organisations address and manage societal concerns about the impacts of their operations, for example in terms of environmental impact (Fernando \& Lawrence, 2014). This paper applies the framework in the context of Big Data, and the disruption that Big Data-enabled business models create. In addition, legitimacy theory identifies groups of evaluators (such as the media) whose judgements can be used to ascertain how legitimate an organisation is, and criteria along which the organisation's propriety and appropriateness can be assessed (the dimensions of legitimacy). The following section describes the method employed in this paper to explore the growing tensions in the relationship between disruptive Big Data companies and society.

\section{Research Approach}

This study applies a multiple case study approach, which explores real-life multiple bounded systems through in-depth analysis of data collected from various sources of information (Creswell, 2007). This approach was chosen because it allows for the empirical study of phenomena in its complexity (McCutcheon \& Meredith, 1993), enabling a holistic and contextualised research, through the collection of a multiple types of data (Hartley, 1994).

\subsection{Case Study Selection}

The study uses instrumental exemplar cases to provide a broader appreciation of how the business models of Big Data companies impact their legitimacy (Stake, 1995). The case studies were selected through purposive sampling, to provide clear, robust and valid insights regarding the impact of each company's business model on society, and how society has reacted to that disruption. This involved selecting information-rich cases, which provide a 'great deal about issues of central importance to the purpose of inquiry' (Patton, 2002, p. 30).

Each of the four instrumental case studies analyses a specific critical event in the history of a well-known Big Data company, which resulted in widespread negative coverage of the company's actions, business failures, legal proceedings and/or the enactment of legislation to outlaw specific Big Data-related disruptive business models. Conceptual aspects discussed in Section 2 also informed the case selection, specifically: which of the $5 \mathrm{Vs}$ each case reflected; what disruptive technologies the company employed; and which legitimacy dimensions appeared challenged by each company's business model. Table 1 summarises the key information on the four selected cases.

\subsection{Data Collection}

The phenomena under analysis are studied in context using a variety of secondary data sources. Multiple data sources were adopted in order to acquire a deeper understanding of the dynamics involved. The aim was twofold: to increase the information base, and to diversify data in order to triangulate findings and reduce bias (Patton, 2002; Yin, 2009), increasing the validity of the findings while also enriching and enhancing their real-world impact (Jonsen \& Jehn, 2009). The data collection consisted of an interactive, funnel-like process, which includes three phases (Fig. 1). 


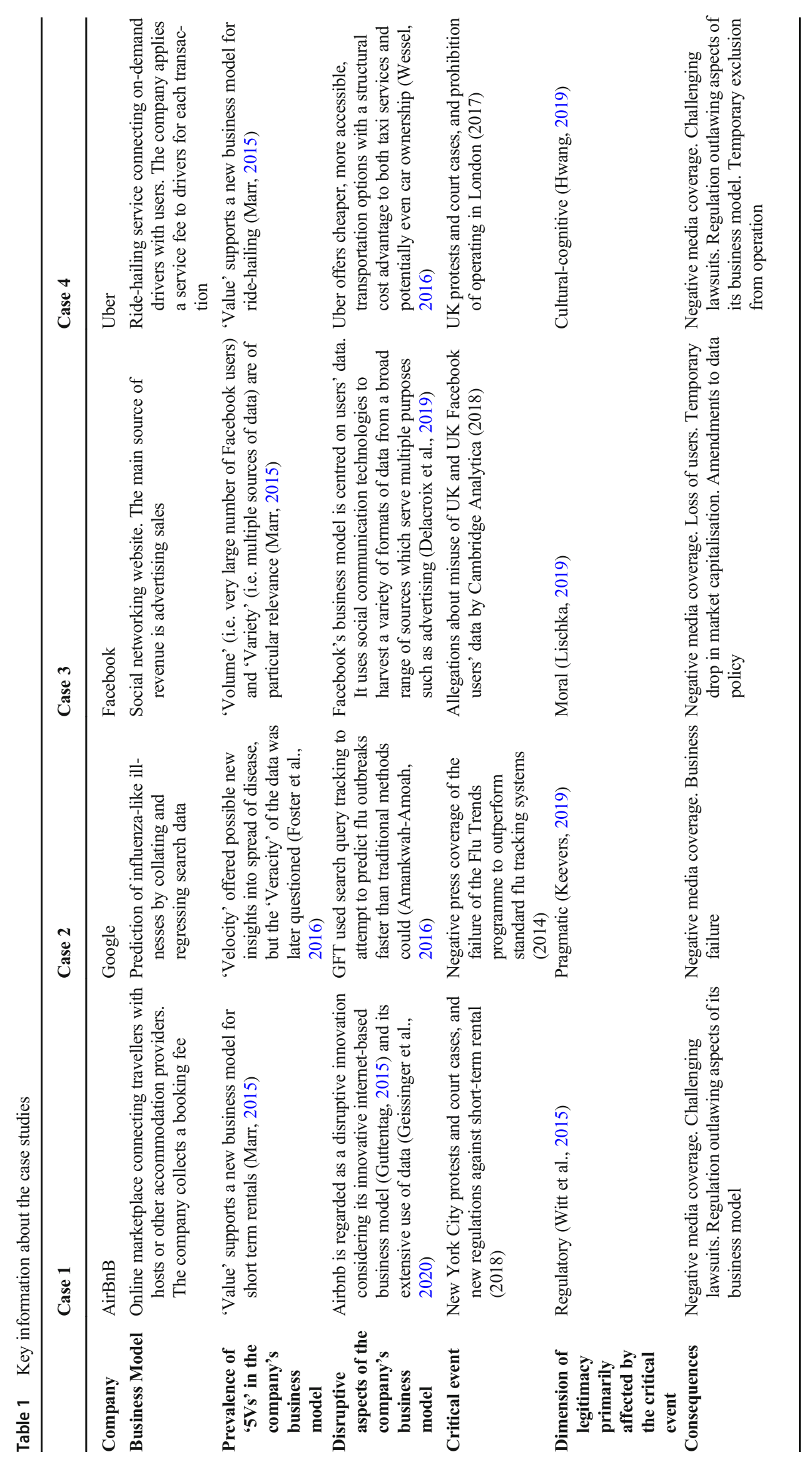


Fig. 1 Data collection process. Adapted from Lozano et al. (2020) $1^{\text {st }}$ Phase:

- $\quad$ generate keywords for search strings

- define inclusion and exclusion criteria

$2^{\text {nd }}$ Phase (1):

- $\quad$ article search, using search strings

- filter by relevant dates

$2^{\text {nd }}$ Phase (2):

- filter by subject area and company name

$2^{\text {nd }}$ Phase (3):

- $\quad$ exclusion of duplicates (129 removed)

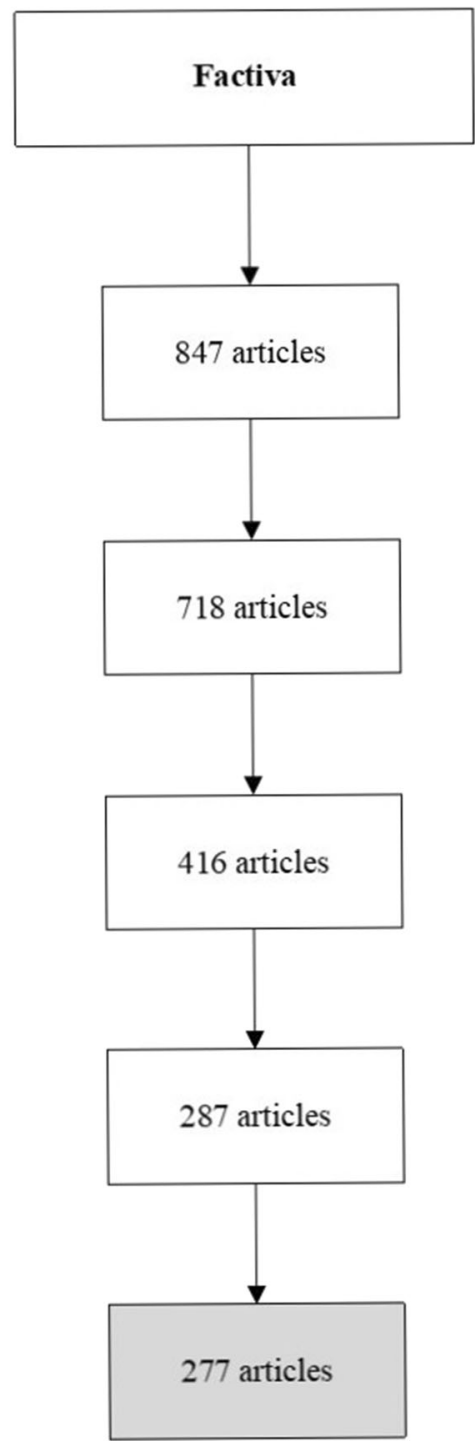

3rd Phase (2): was not available (129 removed)

3rd Phase (3):

- exclusion of articles after final review (10 removed)
- exclusion of articles for which full text 3rd Phase (1):

- exclusion of articles whose first paragraph fails inclusion criteria (302 removed)

\subsubsection{1st Phase}

Through a series of iterations, the research team generated keywords which would serve as search terms, in line with the research objectives and the literature on legitimacy and Big Data (Appendix 1). In addition, the research team chose inclusion and exclusion criteria to screen the data (Appendix 2).

\subsubsection{2nd Phase}

Using the combination of keywords in Appendix 1, articles were extracted using Factiva, an international news database that combines data from a wide range of sources, such as regional, national and international newspapers (e.g., BBC, the Guardian, The New York Times, the Financial Times), magazines (e.g., Forbes), newswires (e.g., Reuters), company reports and material from legal institutions (e.g., the European Court of Justice). The number was then restricted using subject filters of articles, selecting areas (e.g., Science \& Technology or Business) which were pertinent to the research objectives, and the filter 'Company Name'. For each case study, data were collected from the year when the critical event occurred through to the last data available at the time of data collection (October 2019). By applying the keywords previously agreed, 847 articles were initially identified. Of 
Table 2 Representative quotes

\begin{tabular}{|c|c|}
\hline Code & Quote \\
\hline $\begin{array}{l}\text { Regulatory } \\
\text { legitimacy }\end{array}$ & $\begin{array}{l}\text { “'Some governments have rules requiring platforms like Airbnb to collect and remit taxes, and we make every attempt to comply } \\
\text { with these obligations," says Christopher Nulty, Airbnb's head of public policy. "However, many governments do not have } \\
\text { such rules and so Airbnb has proactively established more than } 500 \text { voluntary collection agreements globally to ensure our } \\
\text { community is paying their fair share of taxes. We are eager to do everything we can to ensure we are paying our fair share and } \\
\text { willing to work with any government that will work with us."” (Martineau, 2019) } \\
\text { "Facebook failed to keep the personal information of its users secure by failing to make suitable checks on developers using its } \\
\text { platform". (Waterson, 2018b) }\end{array}$ \\
\hline $\begin{array}{c}\text { Legitimation } \\
\text { strategies }\end{array}$ & $\begin{array}{l}\text { "This system is not designed to be a replacement for traditional surveillance networks or supplant the need for laboratory-based } \\
\text { diagnosis. The data are most useful as a means to spur further investigation and collection of direct measures of disease } \\
\text { activity". (Ward, 2014) } \\
\text { "Recently, the company has tried to appease local authorities by attempting to abide by local laws. It now says it conforms to all } \\
\text { local rules and works only with independent, licensed minicab professionals". (Murgia, 2017) }\end{array}$ \\
\hline Data actor & $\begin{array}{l}\text { "The failures have continued. As Lazer et al. show in their Science study, Google Flu was wrong for } 100 \text { out of } 108 \text { weeks since } \\
\text { August 2011." (Salzberg, 2014) } \\
\text { "In 2016, he [an Uber driver] and another London Uber driver, Yaseen Aslam, brought a worker's rights claim against the } \\
\text { company, arguing that drivers aren't true independent contractors and should instead be classified under the U.K.'s third } \\
\text { employment category of "worker"-entitling them to minimum wage and paid vacation days. Farrar's team won the } \\
\text { classification case". (Holder, 2019) }\end{array}$ \\
\hline
\end{tabular}

these, 240 were about Airbnb in New York; 156 about Google Flu Trends; 198 about Facebook; and 253 about Uber in the UK. 129 duplicates were removed (40 about Airbnb, 15 about Facebook, 35 about GFT and 39 about Uber), and the remaining 718 articles merged with the dataset.

\subsubsection{3rd Phase}

To reduce potential biases or errors, the three members of the research team reviewed the first paragraph of each article (in absence of an abstract) independently, to assess whether it fulfilled the inclusion criteria. This led to the removal of 306 articles, leaving 416 articles in the dataset. The last filtering iteration was based on reading/scanning the full papers, resulting in a set of 287 papers. This final set of articles were read and reviewed in full by the team. On closer analysis, however, ten more articles were removed from the final dataset as they did not fulfil the inclusion criteria. This resulted in a total of 277 articles for analysis: 57 about AirBnB in New York; 65 about Google Flu Trends; 74 about Facebook; and 81 about Uber in the UK. The average word count per article for each case study are: 1097 words for Airbnb in New York, 1519 words for GFT, 1417 words for Facebook and 1284 words for Uber in the UK.

\subsection{Data Analysis}

The data analysis was based on an intensive approach, whereby each case was analysed holistically (Eriksson \& Kovalainen, 2016). This resulted in a narrative description of each case's unique workings, deductively framed by the literature discussed in Section 2. The data were analysed using a deductive category application or theory-driven content analysis (Mayring, 2000): a directed approach to content analysis to validate and conceptually extend the theoretical constructs discussed in previous sections (Krippendorff, 2004). In line with Hsieh and Shannon (2005), the data were coded using predetermined keywords which synthesise the theoretical constructs under investigation. This deductive coding agenda (Appendix 3) includes a literature-derived definition for each concept, examples from data and coding rules for each deductive keyword, and specifies under what circumstances a text extract can be coded with a keyword (Mayring, 2000). Drawing on the principles of investigator triangulation (Denzin, 1989), all three members of the research team were involved in the data analysis to help minimise bias and increase confidence in the plausibility of the results. Each researcher coded the data independently, and the findings were then discussed amongst the research team, in order to come to an agreement on the main topics emerging from the data. Intercoder reliability (Krippendorff, 2004) and intercoder agreement (Campbell et al., 2013) were maximised through a systematic approach to the elimination of any discrepancies and redundancies. After various iterations, sufficient consistency and validity was achieved (Zhang \& Wildemuth, 2009). Examples of how parts of the data were coded can be found in Table 2.

\section{Legitimacy Challenges to Big Data Business Models}

This section explores how the legitimacy of the four instrumental cases was affected during and after the critical events 
listed in Table 1. Each case starts with a description of the events that triggered a legitimacy loss. The analysis then identifies the challenges to their legitimacy that the companies faced from a range of stakeholders, and what actions the companies took to attempt to regain their legitimacy. ${ }^{2}$

\subsection{AirBnB - Protests and Court Case in new York City}

AirBnB is an online marketplace that connects people who want to rent out their properties with people who are seeking short-term accommodation. As of late 2019, its website listed more than six million rooms, flats and houses in more than 81,000 cities around the world (Sherwood, 2019). AirBnB's business model has the potential to cause disruption at several levels: for example, hotel owners have complained that the company's low-cost structure, coupled with hosts' reported tax evasion, makes it impossible to compete (Keighran, 2018). The company's business model also creates incentives for investors to buy housing stock for short-term rental purposes (Ferré-Sadurní, 2019), which have been partly blamed for rising rental costs in several cities, leading to protests (Boone, 2018; Hinsliff, 2018; Wachsmuth et al., 2018; Wachsmuth \& Weisler, 2018).

This disruption has resulted in increased legal scrutiny of the company. As a result, AirBnB has been accused of operating an illegal rental market in some jurisdictions. Amongst these is New York City, where property owners are not allowed to rent their properties for less than 30 days if they do not reside there themselves (NYC-OSE, n.d.). Research has shown that a high proportion of AirBnB offers in the city followed that model (Hatmaker, 2018).

\subsubsection{Stakeholders' Reaction}

The situation in New York has led to AirBnB losing legitimacy in the eyes of important stakeholders - not only citizens affected by rising rental costs, but also notably the city government. As a result, a series of laws and regulations have been passed, which directly affect AirBnB's business model. Notably, New York City Council passed new legislation in July 2018 requiring hosts to share their tenants' personal information with the Council, in addition to enforcing the prohibition of short-term leases (Coldewey, 2018). Prior to the global health pandemic that hit the USA in $2020,^{3}$ the legislation looked set to cost AirBnB significant market share in the hospitality sector in New York City.

\footnotetext{
${ }^{2}$ Citations in this Section refer exclusively to empirical materials collected, as per the process described in Section 3. All are denoted with an asterisk in the references list.

3 The impact of the COVID-19 pandemic on AirBnB was not analysed in this paper, as it took place after the data collection cut-off date (October 2019- see Section 3.2).
}

The fallout of the regulatory issues in New York has had a negative impact on AirBnB's business model elsewhere. New short-term rental laws were subsequently introduced in several US cities, such as Boston in January 2019 and Seattle in September 2019 (Simmons, 2019) - suggesting that AirBnB's activities are still subject to challenge and debate. Furthermore, other metropolises look set to follow New York's example: for example, Madrid and Valencia have passed legislation capping the number of days that a given dwelling can be offered for short-term rental in a single year (Coffey, 2017; Spinks, 2018). In France, the government accused AirBnB of not owning an estate agent's licence to operate (Cecco \& Willsher, 2019) and required it to register the rooms or flats in the country in order to rent them out.

\subsubsection{Company's Reaction}

AirBnB has opposed the new regulations in New York, but has so far been unable to change them (Hempel, 2018; Ting, 2017). In order to reduce the impact of future regulation on its business model, the company opted to reexamine its worldwide operations, and to work with the authorities and legislators to ameliorate its social impact. For example, in the UK AirBnB consulted on a government proposal for a register of the identities of its hosts, aimed at preventing illegal short-term renting (Boone, 2018). AirBnB also promised to review and verify every property promoted on its platform by December 2020 (BBC News, 2019b), as an indication of its concern and to demonstrate to regulators and users that its business model is legal.

In its battle to recover its legitimacy, AirBnB secured a victory in a court trial in December 2019. The European Court of Justice ruled that 'it acted as an information society service rather than a real estate agency' (Boffey, 2019), meaning the company does not need a licence to operate in France. A company statement clarifies this point: 'We want to be good partners to everyone and already we have worked with more than 500 governments to help hosts share their homes, follow the rules and pay tax' (Boffey, 2019). AirBnB has also settled lawsuits with San Francisco and New York City (Benner, 2017). The company responded to criticisms by cooperating with legislators and the judiciary system rather than opposing it, saying it intends to create 'a powerful people-to-people based political advocacy bloc' (Hickey \& Cookney, 2016). In summary, AirBnB's offering continues to appeal to many users, as demonstrated by a strong market position (Detlefsen, 2018), but the company is struggling to fend off regulation that would target its business model across multiple locations. 


\subsection{Google - Flu Trends Programme}

Google announced its Google Flu Trends (GFT) programme in 2008, as an application of Google's Trends service. The service used Google search data to predict the spread of influenza-like diseases in the United States (Ginsberg et al., 2009), which is normally predicated on the analysis of laboratory diagnostics by the Centres for Disease Control and Prevention (CDC) (Salzberg, 2014). While at the outset of the programme Google stated that the GFT was not designed to replace existing monitoring networks, it also noted its potential to detect flu outbreaks with a reporting lag of about one day (Ginsberg et al., 2009). As a result, the programme was portrayed by commentators as providing the ability to 'nowcast' the flu based on web users' searches (Lazer \& Kennedy, 2015). GFT quickly became a poster child for the potential of Big Data to disrupt existing disease monitoring and prevention techniques beyond the United States (Madrigal, 2014).

Despite initial promise, GFT soon began to diverge from the observable spread of flu, providing overestimates of the prevalence of the disease and missing the peak by a wide margin for three consecutive years (Arthur, 2014a; Lazer et al., 2014). Google continued to update the algorithm between 2008 and 2014, including building two-week lagged data from the CDC into the GFT algorithm (Madrigal, 2014) before an academic article (Lazer et al., 2014) noted the magnitude of the prediction errors and the reasons behind them. Not long after, Google opted to terminate GFT (Comstock, 2015).

\subsubsection{Stakeholders' Reaction}

In their analysis of the programme's performance, Lazer et al. (2014) suggested two fundamental problems: 'Algorithm Dynamics' and 'Big Data Hubris'. 'Algorithm Dynamics' refers to the continuous refinement of Google's algorithm, which offers suggestions against consumers' searches. These suggestions may prompt more searches about flu-related issues, contributing to over-estimation of the spread of the disease. This suggests that the algorithm directly contributed to GFT making less precise predictions than existing methods the Big Data model performed worse than the legacy systems it sought to replace due to intrinsically Big Data reasons. This problem is compounded by 'Big Data Hubris': the assumption that existing methods of data collection and analysis are inferior to, and can be replaced by, Big Data approaches. This is, perhaps, one of the most problematic aspects of the programme: it appears to have set out to prove, not to test, that Big Data could provide better, more accurate predictions of a widely studied phenomenon (Arthur, 2014a).

The scientific community reacted by publishing further evidence that the algorithm was not able to accurately capture the spread of influenza. The criticism was echoed in the media, raising questions about the usefulness of Big Data in addressing societal issues (Collins, 2013). By publicly failing to surpass the ability of survey data to predict the spread of flu, GFT has contributed to questions being asked about the usefulness and fitness for purpose of Big Data (Arthur, 2014a), and renewed calls for openness in terms of both the algorithms and data used (Lazer \& Kennedy, 2015).

\subsubsection{Company's Reaction}

Google acknowledged the research that demonstrated the inefficacy of their algorithm and the arguments made by critics, while also defending the predictive power and the benefits of the GFT (RT, 2014). The company then launched an improved version of the algorithm underpinning GFT (Lazer et al., 2014), but eventually accepted that their approach was not working, and the service was closed. Since then, GFT has become a by-word for the limits and problems of Big Data approaches (Yakabuski, 2014).

\subsection{Facebook - Cambridge Analytica Event}

Facebook is the world's largest social networking website. At the end of 2019 , the company had roughly 2.5 billion "Monthly Active Users", 1.66 billion of which accessed the website daily (Facebook, 2020). The company is arguably the world's largest marketing platform, with a revenue of over $\$ 69$ million in advertising in the year ending December 31st, 2019 (Facebook, 2020).

In March 2018, it was revealed that 87 million individual users had had their Facebook profile data collected and matched to US electoral registers by Cambridge Analytica (CA), a small British consulting firm which offered services to businesses and political parties seeking to "change audience behaviour" (Osborne, 2018). The data was collected via an apparently innocuous survey app, served to Facebook users, which then also collected users' personal data and preferences. Facebook's design allowed this app not only to collect the personal information of people who agreed to take the survey, but also the personal information of all the people in those users' Facebook network. Ultimately CA acquired data from millions of Facebook users (Cadwalladr \& Graham-Harrison, 2018a), used to construct psychometric profiles of users, with a view to identifying possible 'swing voters' and micro-targeting them with political adverts (Sherr, 2018). CA performed these services for Donald Trump's 2016 presidential campaign (Lewis \& Hilder, 2018), while one of its partner companies did the same for the pro-Brexit Leave campaign in the 2016 Brexit referendum in the UK (Hern, 2019). 


\subsubsection{Stakeholders' Reaction}

In the aftermath of the revelations, Facebook's market value fell by $\$ 35$ bn (White, 2018b). While over the following weeks the company saw its stock recover, it subsequently suffered another pronounced drop in value as evidence emerged that users had been abandoning the platform, especially in Europe (Cherney, 2018). Furthermore, when the Facebook data scandal occurred, the \#DeleteFacebook campaign trended on Twitter and many users publicly noted their intention to close their accounts (Confessore, 2018). On the other hand, there was pressure on Facebook's CEO, Mark Zuckerberg, to make public statements about CA and their usage of users' data (Solon, 2018a). Recent studies in both the USA (Solon, 2018b; Webster, 2019) and the UK (Waterson, 2018a) indicate that Facebook usage is down, particularly among younger people who are choosing alternative social media platforms. But despite this, most users continue to feel compelled to use Facebook (Forbes Agency Council, 2018). In fact, users who deleted Facebook in the aftermath of the CA scandal often continued to use some of the company's services, such as WhatsApp and Instagram (McCarthy, 2018).

Facebook maintains that there was no data breach in this instance, and that the issue is the result of misuse and mishandling of data by CA and its partners (Valdez, 2018). Critics of Facebook and its practices agree with the company on this, noting that extensive data collection and use is exactly Facebook's business model, which exchanges free services for surveillance (Tufekci, 2018). The problem, they claim, is that the company's business model is opaque and unclear (Romano, 2018), and that surveillance is '.. a feature, not a bug' (FranceschiBicchierai et al., 2018). The evidence suggests that the system worked as Facebook intended. Nor was the problem one of legality, in that there were no laws against the sharing of data that took place at the time. Users give their consent to data sharing when signing up to Facebook although there is evidence (Berreby, 2017) that few users, if any, read the legal information that they are required to agree with. The problem in this case relates to the lack of true informed consent in the relationship between Facebook and its users. Commentators have argued that this constitutes a strong violation of widespread ethical and moral principles (e.g., O'Shea, 2018), noting growing privacy concerns (Gupte, 2018) and highlighting a widespread lack of information and understanding regarding personal data (Jenkins, 2018). Moreover, the incident is perceived to have both damaged the reputation of Facebook (e.g., Lee, 2019) and raised questions about the trustworthiness of other firms, even beyond the technology sector (Vincent, 2018).

\subsubsection{Company's Reaction}

In the aftermath of the crisis, Facebook has attempted to conform to users' stated preferences, without jeopardising its business model. Despite its poor reputation for safeguarding users' privacy (Tufekci, 2018), the company has gone some way towards meeting stakeholders' demands by updating its privacy settings (Wong, 2018), and it has admitted that its policy allowed for data misuse (Thompson, 2019). Mark Zuckerberg wrote in a public note to users that 'We have a responsibility to protect your data, and if we can't then we don't deserve to serve you. [...] We also made mistakes, there's more to do, and we need to step up and do it' (Wong, 2018). Despite these efforts, Facebook is facing possible government intervention and regulation of its business model. The company has been threatened with the possibility of being broken up under anti-trust law in the United States (Perriello, 2019; Rahman, 2018), and is having to strongly lobby against regulation across various constituencies (Cadwalladr \& Campbell, 2019). The consequences of loss of legitimacy in the eyes of stakeholders look set to affect Facebook for years to come.

As for CA, the company attempted to dismiss the accusations made against it, denying any wrongdoing and asserting its own expertise and credibility. CA sought to demonstrate that its algorithm, combined with data, was able to create a superior and unique set of records which addressed the desire of many companies to forecast customers' needs (Cadwalladr \& Graham-Harrison, 2018b). However, it was not its technical credibility which was at stake, but it moral and ethical standing: for example, a European Parliament resolution states that CA's deemed technical superiority needs to be legally interpreted as an abuse of power (European Parliament, 2018). Confronted with a powerful public backlash, CA eventually ceased trading (Solon \& Laughland, 2018; White, 2018a).

\subsection{Uber - UK Protests and Court Cases}

Uber, a ride-hailing service, operates an online market wherein drivers log on to an app that directs them to collect passengers. More practical for consumers than a taxi service and offering flexible hours to workers, Uber saw high rates of uptake. However, the company stands accused of unfair work practices: by considering each of its many drivers as a service provider and not an employee, Uber does not acknowledge the need to provide any employment benefits, including holiday pay, paid sick leave, or minimum wage (O'Connor, 2017; Parkinson, 2017). The disruption, in this case, consists of a fundamental upending of the traditional social contract between companies and workers. The company has been rocked by a barrage of driver strikes (e.g., BBC News, 2019a), loss of license to operate in London (e.g., Topham, 2019) and attacks 
in the press and social media, focusing on its work welfare practices (e.g., Isaac, 2019; Levin, 2017).

\subsubsection{Stakeholders' Reaction}

Uber drivers in the UK have gone on strike on multiple occasions (Butler, 2019) and have sued the company in an attempt to secure their workers' rights. The UK High Court ruled that Uber drivers are indeed employees of the company, and are consequently entitled to employment benefits (Evans, 2017; Ram \& O'Connor, 2017; Temperton, 2018). The company appealed the ruling to the UK Supreme Court. ${ }^{4}$ Despite being offered a temporary reprieve to comply with UK employment regulations in 2018 (BBC News, 2018), Uber eventually lost its license to operate in London, in part due to their inability to register and assure the identities and rights of their drivers (Thomson et al., 2019). The company's shareholders noted the problems emerging from the company's practices in a letter to Uber founder and then-CEO, Travis Kalanick, explicitly criticising the firm's failure to comply with prevalent social norms: 'The cultural values of Uber need to be transformed to embrace transparency, diversity and social responsibility alongside growth and the bottom line' (Newcomer \& Rosenblatt, 2019). Mr. Kalanick was forced to resign in 2017 (Satariano, 2018).

\subsubsection{Company's Reaction}

Uber initially attempted to demonstrate the superiority of their business model by aggressively promising to challenge the regulator in court over the anti-competitive ruling. Later, Uber decided to conform with existing employment regulations (BBC News, 2018) in order to continue to operate in strategic cities, such as London. However, the company's efforts were deemed insufficient, and Uber was temporarily banned from operating in London, with the regulator (Transport for London - TfL) noting that it was not a 'fit and proper private car hire operator' (TfL, 2019). Uber proceeded to address regulators' requests, including improving Uber passengers' safety and security by making changes to the app and the terms and conditions of drivers (Abril, 2019). Arguably, the company is struggling to re-establish itself as a legitimate business in the eyes of regulators, especially at city level. Commentators have continued to question whether Uber is interested in passing the test of being a 'fit and proper' organisation to hold a minicab licence (Financial

\footnotetext{
${ }^{4}$ On the 19th ${ }^{\text {of }}$ February 2021, the UK's Supreme Court ruled that Uber's drivers are not self-employed, but rather employees of the company. This means drivers would be entitled to benefits such as minimum wage and holiday pay, which have the potential to severely impact the company's bottom line (Russon, 2021). This event was not analysed in this paper, as it took place after the data collection cut-off date, but is referred to here as it a relevant aspect of the case.
}

Times, 2017), or whether it is more interested in distancing itself from its responsibilities (Hoggins, 2019).

\subsection{Summary}

The cases analysed show different results in terms of how companies' actions can affect the four dimensions of legitimacy. The two cases in which the companies use Big Data approaches to serve as market-makers, connecting buyers and sellers - AirBnB and Uber - are both threatened in terms of regulatory legitimacy. In line with Suddaby et al. (2017), regulators have coercive power to ensure compliance, as organisations need regulatory approval to operate (Zimmerman and Zeitz, 2002). Both Uber and AirBnB's newly created markets attempt to circumvent regulations put in place to protect the investment of existing actors (renters and holders of a taxi medallion, respectively). The subsequent reaction - new regulation, outlawing of their practices in places - has had important consequences for the companies.

All but one of the cases analysed complied with the idea of pragmatic legitimacy; only GFT failed to deliver on its technical promise. For organisations that adopt innovative practices, products or services, diffusion of their technology and their ultimate success will be based on their technical superiority (Deephouse et al., 2017). By failing to demonstrate and persuade stakeholders of the usefulness of their algorithms (Suchman, 1995), GFT not only failed, but arguably became a cautionary tale of the shortcomings of Big Data.

Moral legitimacy appears to be a more delicate dimension for Big Data companies to manoeuvre. The analysis indicates that in three of the cases (AirBnB, Facebook and Uber) there was a failure to comply with existing moral norms in societies. This does not necessarily mean that all individuals aware of the issues condone the companies' actions. In fact, it is likely that many of the users of AirBnB, Facebook and Uber are untroubled by the companies' actions, or may even support them (Bitektine \& Haack, 2015). But the actions of the companies have demonstrably gone against principles of fair pricing in housing, freedom from intrusion and unethical attempts to manipulate voting intention, and workers' rights. These actions have resulted in negative headlines, societal-wide disapproval and legal action. Erosion of moral legitimacy has arguably produced some of the strongest reactions against the companies.

All the cases show an erosion of the companies' culturalcognitive legitimacy, which, as noted, is strongly associated with the 'taken-for-grantedness' of organisations (Tost, 2011). The desirability and fit of each of the four companies studied has been publicly debated, and the companies have been the target of political and legal action, besides loss of earnings (Tost, 2011). By losing their cultural-cognitive legitimacy, each of the companies saw its 'taken-for-grantedness' eroded. 
The analysis of the critical cases indicates that the four dimensions of legitimacy should not be viewed as completely distinct, as a failure that appears to be principally located in one dimension of legitimacy can still have repercussions in other dimensions. Similarly, the findings suggest that there is no simple correspondence between the four dimensions of legitimacy and the recognised strategies for legitimacy recovery (conforming, decoupling and performing). The analysis shows that the four case companies adopted a range of strategies in an attempt to recover their legitimacy.

In the main, AirBnB and Facebook adopted 'conforming' strategies. While we see elements of the other strategies, such as insisting on the excellence and superiority of their offerings, they largely sought to conform to legislators' demands and users' preferences. This is consistent with previous studies that found that organisations adapt their practices in response to legal demands, even where there is no clear economic or technical advantage to doing so (Suddaby et al., 2017; DiMaggio \& Powell, 1983; Tolbert \& Zucker, 1983). In the case of Uber, there is evidence of 'decoupling' and 'performing' strategies, at least initially. The company appeared to superficially conform to some legal demands while seeking to demonstrate that its business model was innovative and technically superior. When this blend of strategies did not lead to entirely positive results, the company sought to develop a 'conforming' strategy, complying with new regulations. In a similar vein, GFT adopted a mix of 'performing' and 'conforming' strategies - arguing for the technical superiority of its algorithms while simultaneously admitting to some of its limitations and working with other stakeholders. Over time, GFT faced growing pressure over the validity of its modelling, and sought to conform by adopting some of the methodological prescriptions of external experts.

\section{Discussion}

This section discusses the paper's key conceptual contributions.

\subsection{The Legitimacy-Disruption Paradox: A Continuum}

Big Data and analytics ecosystems have the potential to promote positive digital transformations of societies (Pappas et al., 2018). However, findings from the cases analysed in this paper show that Big Data companies' business models can disrupt more than a given industry or sector. The power of Big Data-enabled business models is such that the companies concerned have the potential to disrupt much broader aspects of social organisation. This, in turn, leads to debates about the propriety and fitness of these business models, and to calls for regulation against their impacts. At this point, legitimacy theory makes the prediction that the companies would make every effort to recover their legitimacy. Legitimacy is portrayed in the literature as a property which enables organisations to operate, and the loss of which can constitute a threat to those same organisations (Bitektine, 2011; Deephouse et al., 2017; Ferreira et al., 2019; Gollnhofer, 2017; Tost, 2011). However, the findings suggest a more nuanced view. When organisations set out to be disruptive and produce (digital) transformations of societies (as per the DTS), they face a paradox: because their business models require them to disrupt the ways in which the economy is organised, their aim cannot be to become fully legitimate. Figure 2 illustrates the two opposing pressures on Big Data companies, which we refer to as the legitimacy-disruption paradox.

The findings suggest that Big Data organisations' legitimacy is negatively related to the disruption caused by its business model. As a result, the paradox places the two dimensions legitimacy and disruption - along the same axis. The levels of legitimacy (noted above the axis in Fig. 2) refer to the legitimacy evaluation of an organisation, proposed by Deephouse et al. (2017). Illegitimate refers to an organisation whose stakeholders oppose its existence in its current form. An organisation is Debated if its actions and fundamental values are actively challenged and questioned in the social system, and Proper refers to an organisation which is seen as legitimate, subject to external audit. Finally, an Accepted organisation's existence is entirely taken-for-granted and beyond debate (Deephouse et al., 2017). Below the axis are two levels of perceived disruption caused by the Big Data organisation, from Lower Disruption to Higher Disruption. As the Big Data organisation's business model results in higher disruption its legitimacy will drop, and vice-versa.

The legitimacy-disruption paradox forces organisations in the Big Data space to undertake a dynamic management of their legitimacy, which must be continuously balanced against the need to be disruptive. These companies have to accept lower levels of legitimacy (Proper or Debated), rather than

Fig. 2 The legitimacy-disruption paradox. Source: authors

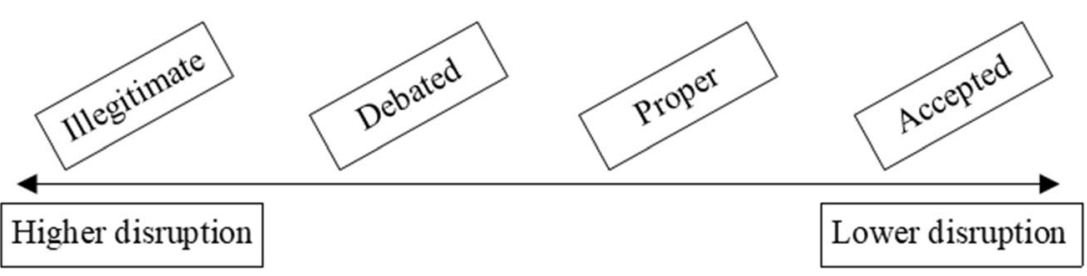


aim for a fully Accepted level of legitimacy, otherwise their ability to be disruptive is limited. However, they still need to avoid becoming completely Illegitimate, as it is possible that the subsequent reaction from society will be sufficiently violent to severely affect their bottom line, as felt by AirBnB in New York and Uber in the UK.

The legitimacy-disruption paradox goes some way towards accounting for the companies' difficulty in addressing the challenges to their legitimacy, as reported in the cases. Only after insisting on the superiority of their business models and failing to recover their legitimacy in the process did the companies attempt to (partially) align their operations with practices and norms in society. However, the organisations' core business models were not substantially changed; instead, the companies made comparatively small changes which brought them from the far left of Fig. 2 (Highly Disruptive and Illegitimate) and towards the centre (less disruption, but still Debated). Each continued to be disruptive for society, but somewhat less so; their legitimacy continued to be contested, but less fiercely so. This dynamic is likely to continue as the impact of Big Data over the way society is organised plays out.

The first research question this paper set out to address was as follows: in what ways does the disruptive innovation caused by Big Data business models affect Big Data organisations' legitimacy? The findings show that the disruption caused by their business models erodes the companies' legitimacy, often across more than one of the dimensions of legitimacy. The companies then face the need to dynamically manage their legitimacy level by engaging external stakeholders and effecting moderate changes to their business models, in order to regain some legitimacy while continuing to be disruptive. This suggests the need to account for legitimacy in models which attempt to theorise how Big Data can effect transformations in society. This is explored in the next section.

\subsection{Legitimacy, Stakeholders and Societal Change}

The DTS model (Pappas et al., 2018) aims to conceptualise the factors that Big Data ecosystems need to have in order to enable digital transformation, resulting in business transformation and value creation. This paper expands on the DTS model, by explicitly noting the importance of societal factors. The findings in this paper show that Big Data organisations need to dynamically manage their legitimacy, treating it as transient rather than permanent (Suddaby et al., 2017). This means that Big Data companies constantly need to put forward strategies to safeguard or recover their legitimacy. If Big Data organisations are not legitimate, they will fail to create value and generate business and societal change in a way that the entire ecosystem can benefit from. These insights result in the Updated DTS model (Fig. 3).

The Updated DTS model explicitly includes the social dimension under a newly added component, "Legitimising Big Data Organisations" (third box from the left), placed alongside the "Data Actors" and "Big Data Analytics Capability". At the core of this new component in the need for "Managing the Legitimacy-Disruption Paradox". As noted above, the legitimacy of these companies must be managed in a dynamic fashion. This is because the "Disruptive Innovation" they base their business models on can result in "Threatened Legitimacy". Even as the organisation recovers legitimacy, it is likely to use Big Data to produce other disruptive innovations, which may threaten its legitimacy again. As a result, the third aspect of the triangle in Fig. 3 is the "Legitimation Strategies" the company must develop to address new legitimacy challenges. The findings of this study show that Big Data companies do not necessarily apply a specific strategy but a combination of them. This adds to the disruptive innovation and legitimacy literature, where there is growing evidence that encapsulating legitimation into static strategies can only partially address the challenges posed by disruptive innovation (Ben-Slimane et al., 2020; Patala et al., 2019; Suddaby et al., 2017). The findings suggest that the legitimacy

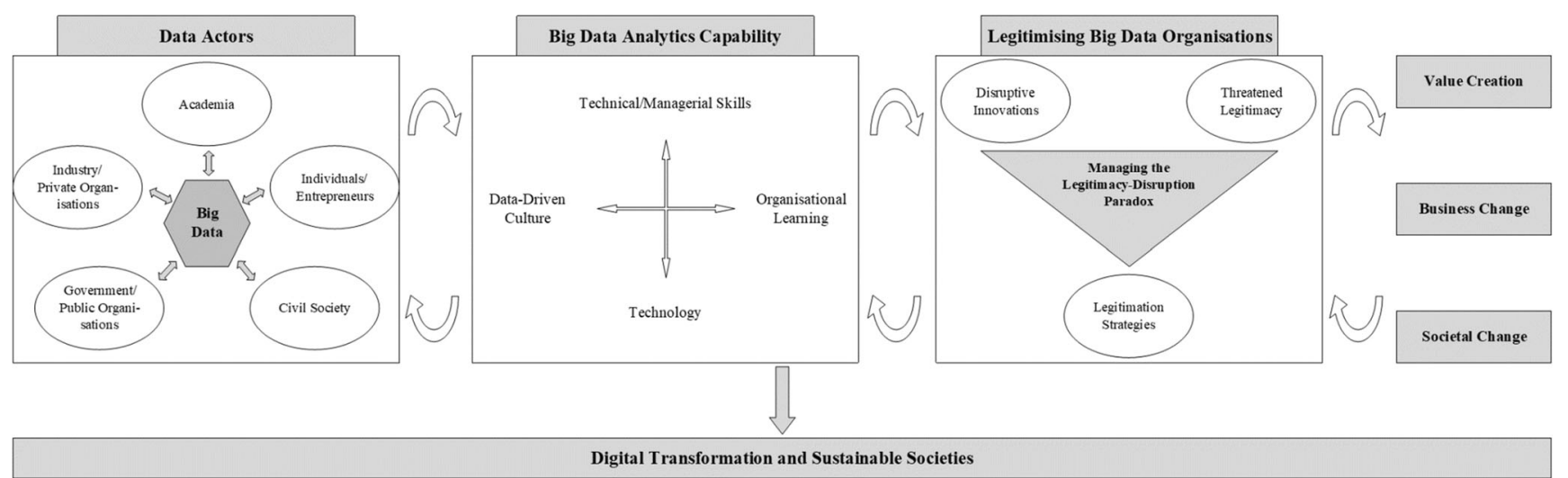

Fig. 3 Updated DTS model. Source: authors, adapted from Pappas et al. (2018) 
dimensions and strategies contribute, in a mutual, simultaneous and interconnected way, to the survival and strength of Big Data organisations within a disruptive innovative environment.

The second research question that this paper set out to address was as follows: how can Big Data organisations manage the challenges to their legitimacy? The findings suggest that these companies need to combine existing legitimation strategies, and potentially develop new ones, in order to dynamically manage their position in society. If a company needs to continue to operate in the range of Proper to Debated legitimacy, this must be kept under continuous review by managers. Furthermore, social values are also dynamic. Firms like Airbnb, Facebook and Uber have both adapted themselves to, and pushed back against, the pressures they experienced. They appear to feel both supported by users who see the benefits of their new business models, and challenged by stakeholders who point to the downsides of their disruptive innovations. Big Data firms must consider the different dimensions of legitimacy discussed here as, over time, changes that improve their position against one dimension might damage their standing with regard to another dimension of legitimacy. For example, a move that enhances their position regarding regulation or moral values might damage their ability to deliver what is perceived to be an attractive service to users. The legitimacy-disruption paradox can help managers to understand and explore these challenges as they play out over time. The positioning of the paradox within the DTS model highlights the societal side of the transformations at play. Digital transformation must be considered not only in relation to value creation and business change, but also in relation to societal change - and legitimacy theory is a valuable lens for articulating and elaborating the key issues of societal disruption driven by Big Data.

\section{Big Data, Disruption and Legitimacy: Which Way Forward?}

This paper has analysed how society evaluates Big Data business models, in the light of the disruption they can cause. It found that Big Data companies need to dynamically manage their legitimacy level, not attempt to become entirely legitimate. As a result of this, the companies may need to enhance or merge existing legitimation strategies, or develop entirely new ones.

\subsection{Conceptual Contributions}

The paper makes two conceptual contributions. First, the legitimacy-disruption paradox elaborates the challenges faced by companies employing Big Data-driven business models.
The model stipulates that there is an inverse relation between the disruption caused by a company and its legitimacy. Big Data companies need to identify a workable trade-off between promoting disruptive changes and fitting with existing social norms and values. This goes beyond previous understandings of legitimacy as a dimension which all companies seek to maximise. Instead, this paper argues, companies may wish to actively manage their legitimacy level, trading off some social fit for the ability to be more aggressively disruptive. However, this dynamic management must be carefully judged, as greater levels of disruption may lead to the organisation being seen as illegitimate, and penalised accordingly.

Second, the paper extends the DTS model (Pappas et al., 2018), in the light of the legitimacy-disruption paradox, by explicitly including social dimensions and the management of the organisations' legitimacy. Where the original DTS focused on technical competences and human skills, the Updated DTS explicitly highlights that transformations can often face opposition. While Big Data can enable organisations to produce net positive outcomes, it can also affect groups of stakeholders. Failure to legitimise transformative business models can result in their failure.

\subsection{Implications for Practice}

The results suggest various implications for practice. First, it is more likely that an innovative project that is kept 'at arm's length' from the core business (e.g., GFT) can be terminated without significant damage to the organisation's other activities. This appears to be a safer way to proceed if a project is deemed to bring a high level of risk.

Second, managers of Big Data businesses should consider making use of a tool such as the legitimacy-disruption paradox depicted in Fig. 2, in order to articulate the nature and level of disruption that their business model may entail. This can assist them in identifying and debating actions to adapt their activities to a more acceptable position, or indeed to push the boundaries of acceptability and attempt to promote a shift in societal values and judgements. Managers can also help address this by building considerations about legitimacy into their strategic thinking.

Third, although existing theory suggests that legitimacy has four distinct dimensions, it is important for managers to consider that erosion of one dimension of legitimacy (for example, violating moral or fairness principles) may result in pushback across other dimensions (such as regulation or loss of users). Managers need to view legitimacy as both an overarching idea and one that is built on several dimensions. For management scholars, further work is needed to develop the theory of legitimacy as both a holistic and multi-dimensional concept. 


\subsection{Limitations and Future Research}

The study has several limitations, which lead to suggestions for future research. First, some organisations are likely to experience explicit challenges to more than one legitimacy dimension. The four critical cases were selected to provide a primary focus on the dominant legitimacy dimension. However, the findings highlight that a loss of legitimacy in one area can have consequences in other areas. Future research should address instances of a loss of legitimacy across multiple dimensions.

Second, as the four case studies focus on international companies, it is likely that they may have faced other challenges in different countries. However, this paper focused on a specific critical incident, at a given time and in a given locality. Future studies should adopt an international dimension on incidents of loss of legitimacy, elaborating on the impact of an incident in one locality on the organisation's status across multiple geographic locations.

Third, the methodological approach of the study - based on secondary data relating to four critical cases - did not allow the researchers to adopt a longitudinal approach. A future study based on a single, in-depth case would allow scholars to analyse how an organisation responds to legitimacy loss, and study its legitimacy recovery strategies over time. Such a study could also seek to gather primary data from key data actors such as employees and customers.

Finally, future research based on this paper's contributions should assess how specific business models can affect companies' preferred position along the legitimacy-disruption paradox. Related to this, future research should also investigate the mechanisms by which companies can contribute to shifting society's values, making previously illegitimate positions debated and/or legitimate.

Supplementary Information The online version contains supplementary material available at https://doi.org/10.1007/s10796-021-10155-3.

\section{References}

References Preceded by an Asterisk Refer to Empirical Materials Collected for the Analysis and Cited in the Text, Tables or Annexes

*Abril, D. (2019). Uber Launches New Safety Features for Fighting Fake Drivers. Fortune. https://fortune.com/2019/09/26/uber-debutssaftey-features-riders-drivers/. Accessed 24 June 2020.

Amankwah-Amoah, J. (2016). Emerging economies, emerging challenges: Mobilising and capturing value from big data. Technological Forecasting and Social Change, 110, 167-174. https://doi.org/10.1016/j.techfore.2015.10.022.

*Arthur, C. (2014a). Google flu trends is no longer good at predicting flu, scientists find. The Guardian. https://www.theguardian.com/ technology/2014/mar/27/google-flu-trends-predicting-flu. Accessed 16 August 2018.

*BBC News. (2018). Uber granted short-term London licence. BBC News. https://www.bbc.com/news/business-44612837. Accessed 24 August 2018.

*BBC News. (2019a). Uber drivers strike in UK and US. BBC News. https://www.bbc.com/news/business-48190176. Accessed 17 June 2020.

*BBC News. (2019b). Airbnb will verify listings, 11 years after launch. $B B C$ News. https://www.bbc.com/news/technology-50315546. Accessed 7 January 2020 .

Bean, R. (2018). How big data and AI are driving business innovation in 2018. MIT Sloan Management Review. https://sloanreview.mit.edu/ article/how-big-data-and-ai-are-driving-business-innovation-in2018/. Accessed 13 May 2020.

*Benner, K. (2017). Airbnb settles lawsuit with its hometown, San Francisco. The New York Times. https://www.nytimes.com/2017/ 05/01/technology/airbnb-san-francisco-settle-registration-lawsuit. html. Accessed 14 January 2020.

Ben-Slimane, K., Diridollou, C., \& Hamadache, K. (2020). The legitimation strategies of early stage disruptive innovation. Technological Forecasting and Social Change, 158, 120161. https://doi.org/10. 1016/j.techfore.2020.120161.

*Berreby, D. (2017). Click to agree with what? No one reads terms of service, studies confirm. The Guardian. https://www.theguardian. com/technology/2017/mar/03/terms-of-service-online-contractsfine-print. Accessed 14 January 2020.

Bharati, P., \& Chaudhury, A. (2019). Assimilation of big data innovation: Investigating the roles of IT, social media, and relational capital. Information Systems Frontiers, 21(6), 1357-1368. https://doi.org/ 10.1007/s10796-018-9839-6.

Bitektine, A. (2011). Toward a theory of social judgments of organizations: The case of legitimacy, reputation, and status. Academy of Management Review, 36(1), 151-179. https://doi.org/10.5465/amr. 2009.0382

Bitektine, A., \& Haack, P. (2015). The "macro" and the "micro" of legitimacy: Toward a multilevel theory of the legitimacy process. Academy of Management Review, 40(1), 49-75. https://doi.org/10. 5465/amr.2013.0318.

Blazquez, D., \& Domenech, J. (2018). Big data sources and methods for social and economic analyses. Technological Forecasting and Social Change, 130, 99-113. https://doi.org/10.1016/j.techfore. 2017.07.027.

*Boffey, D. (2019). EU court rules Airbnb does not require estate agent licence. The Guardian. https://www.theguardian.com/technology/ 2019/dec/19/eu-court-rules-airbnb-does-not-require-estate-agentslicence. Accessed 7 January 2020.

*Boone, A. (2018). What Airbnb did to new York City. CityLab. https:// www.citylab.com/equity/2018/03/what-airbnb-did-to-new-yorkcity/552749/. Accessed 13 August 2018.

Braganza, A., Brooks, L., Nepelski, D., Ali, M., \& Moro, R. (2017). Resource management in big data initiatives: Processes and dynamic capabilities. Journal of Business Research, 70, 328-337. https:// doi.org/10.1016/j.jbusres.2016.08.006.

Brown, N., \& Deegan, C. (1998). The public disclosure of environmental performance information - A dual test of media agenda setting theory and legitimacy theory. Accounting and Business Research, 29(1), 21-41. https://doi.org/10.1080/00014788.1998.9729564.

*Butler, S. (2019). Uber drivers in UK cities strike over pay and conditions. The Guardian. https://www.theguardian.com/technology/ 2019/may/08/uber-drivers-in-uk-cities-strike-over-pay-andconditions

*Cadwalladr, C., \& Campbell, D. (2019). Revealed: Facebook's global lobbying against data privacy laws. The Observer. https://www. theguardian.com/technology/2019/mar/02/facebook-global- 
lobbying-campaign-against-data-privacy-laws-investment. Accessed 7 January 2020.

*Cadwalladr, C., \& Graham-Harrison, E. (2018a). Revealed: 50 million Facebook profiles harvested for Cambridge Analytica in major data breach. The Guardian. https://www.theguardian.com/news/2018/ mar/17/cambridge-analytica-facebook-influence-us-election. Accessed 16 August 2018.

*Cadwalladr, C., \& Graham-Harrison, E. (2018b). How Cambridge Analytica turned Facebook 'likes' into a lucrative political tool. The Guardian. https://www.theguardian.com/technology/2018/ mar/17/facebook-cambridge-analytica-kogan-data-algorithm. Accessed 7 January 2020.

Campbell, J. L., Quincy, C., Osserman, J., \& Pedersen, O. K. (2013). Coding in-depth Semistructured interviews: Problems of unitization and Intercoder reliability and agreement. Sociological Methods \& Research, 42(3), 294-320. https://doi.org/10.1177/ 0049124113500475.

Cashmore, M., \& Wejs, A. (2014). Constructing legitimacy for climate change planning: A study of local government in Denmark. Global Environmental Change, 24, 203-212. https://doi.org/10.1016/j. gloenvcha.2013.09.019.

*Cecco, L., \& Willsher, K. (2019). Airbnb faces backlash in Toronto and Paris. The Guardian. https://www.theguardian.com/world/2019/ nov/19/olympic-committee-deal-airbnb-angers-paris-authorities. Accessed 6 January 2020.

Chen, C. L. P., \& Zhang, C.-Y. (2014). Data-intensive applications, challenges, techniques and technologies: A survey on big data. Information Sciences, 275, 314-347. https://doi.org/10.1016/j.ins. 2014.01.015.

*Cherney, M. A. (2018). Facebook stock drops roughly 20\%, loses $\$ 120$ billion in value after warning that revenue growth will take a hit. MarketWatch. https://www.marketwatch.com/story/facebookstock-crushed-after-revenue-user-growth-miss-2018-07-25. Accessed 20 August 2018.

Christensen, C. M. (1997). The innovator's dilemma: when new technologies cause great firms to fail (paperback.). Harvard Business Review Press.

*Coffey, H. (2017). Strict new rules imposed on Airbnb rentals in Paris. The Independent. http://www.independent.co.uk/travel/news-andadvice/airbnb-paris-rules-new-rental-limit-bookings-stay-nightslatest-a8054771.html. Accessed 15 August 2018.

*Coldewey, D. (2018). New law forces Airbnb to open its books to New York authorities. TechCrunch. http://social.techcrunch.com/2018/ 07/18/new-law-forces-airbnb-open-its-books-to-new-yorkauthorities/. Accessed 15 August 2018.

*Collins, G. (2013). Opinion | the flu. Who knew? The New York Times. https:/www.nytimes.com/2013/01/12/opinion/collins-the-flu-whoknew.html. Accessed 7 January 2020.

*Comstock, J. (2015). Google flu trends website shuts down; will send data to Boston Children's, Columbia, CDC. MobiHealthNews. https://www.mobihealthnews.com/46248/google-flu-trendswebsite-shuts-down-will-send-data-to-boston-childrens-columbiacdc. Accessed 7 January 2020

*Confessore, N. (2018). Cambridge Analytica and Facebook: The Scandal and the Fallout So Far. The New York Times. https:// www.nytimes.com/2018/04/04/us/politics/cambridge-analyticascandal-fallout.html. Accessed 7 January 2020.

Creswell, J. W. (2007). Qualitative inquiry \& research design: Choosing among five approaches (2nd ed.). Sage Publications.

Deegan, C. (2002). Introduction: The legitimising effect of social and environmental disclosures - A theoretical foundation. Accounting, Auditing \& Accountability Journal, 15(3), 282-311. https://doi.org/ 10.1108/09513570210435852.

Deephouse, D. L., Bundy, J., Tost, L. P., \& Suchman, M. C. (2017). Organizational legitimacy: Six key questions. In R. Greenwood,
C. Oliver, T. Lawrence, \& R. Meyer (Eds.), The SAGE handbook of organizational institutionalism (2nd ed.). SAGE.

Degli Esposti, S. (2014). When big data meets dataveillance: The hidden side of analytics. Surveillance \& Society, 12(2), 209-225. https:// doi.org/10.24908/ss.v12i2.5113.

Delacroix, E., Parguel, B., \& Benoit-Moreau, F. (2019). Digital subsistence entrepreneurs on Facebook. Technological Forecasting and Social Change, 146, 887-899. https://doi.org/10.1016/j.techfore. 2018.06.018.

Denning, S. (2016). Christensen updates disruption theory. Strategy \& Leadership, 44(2), 10-16. https://doi.org/10.1108/SL-01-20160005.

Denzin, N. K. (1989). The research act: a theoretical introduction to sociological methods (3rd ed.). Englewood cliffs, N.J: Prentice hall.

*Detlefsen, H. (2018). Airbnb's Market Share of U.S. Lodging Demand Increasing at a Decelerating Rate. Hotel Online. https://www.hotelonline.com/press_releases/release/airbnbs-market-share-of-u.s.lodging-demand-increasing-at-a-decelerating-ra. Accessed 24 August 2018.

DiMaggio, P. J., \& Powell, W. W. (1983). The Iron cage revisited: Institutional isomorphism and collective rationality in organizational fields. American Sociological Review, 48(2), 147. https://doi.org/10. 2307/2095101.

Erevelles, S., Fukawa, N., \& Swayne, L. (2016). Big data consumer analytics and the transformation of marketing. Journal of Business Research, 69(2), 897-904. https://doi.org/10.1016/j.jbusres.2015. 07.001 .

Eriksson, P., \& Kovalainen, A. (2016). Qualitative methods in business research (2nd ed.). SAGE.

*European Parliament. (2018). MOTION FOR A RESOLUTION on the use of Facebook users' data by Cambridge Analytica and the impact on data protection. http://www.europarl.europa.eu/doceo/document/ B-8-2018-0480_EN.html. Accessed 7 January 2020.

*Evans, J. (2017). Uber drivers are 'workers' - but why does this matter? The Law Blog (Blawg). http://www2.cipd.co.uk/community/blogs/ b/the blawg/archive/2017/11/14/uber-drivers-are-workers-butwhy-does-this-matter. Accessed 15 August 2018.

*Facebook. (2020). Facebook Reports Fourth Quarter and Full Year 2019 Results. https://investor.fb.com. https://investor.fb.com/investornews/press-release-details/2020/Facebook-Reports-Fourth-Quarterand-Full-Year-2019-Results/default.aspx. Accessed 8 June 2020.

Fernando, S., \& Lawrence, S. (2014). A theoretical framework for CSR practices: Integrating legitimacy theory, stakeholder theory and institutional theory. Journal of Theoretical Accounting Research, 10(1), 149-178.

Ferreira, C., Merendino, A., \& Meadows, M. (2019). How big data can destroy organisations' legitimacy. International Corporate Rescue, 16(3), 174-176.

*Ferré-Sadurní, L. (2019). Inside the Rise and Fall of a MultimillionDollar Airbnb Scheme. The New York Times. https://www. nytimes.com/2019/02/23/nyregion/airbnb-nyc-law.html. Accessed 16 June 2020.

*Financial Times. (2017). How Uber and London ended up in a taxi war. Financial Times. https://www.ft.com/content/41a0ff40-a383-11e79e4f-7f5e6a7c98a2

*Forbes Agency Council. (2018). Key takeaways from the FacebookCambridge Analytica data scandal. Forbes. https://www.forbes. $\mathrm{com} / \mathrm{sites} /$ forbesagencycouncil/2018/05/13/key-takeaways-fromthe-facebook-cambridge-analytica-data-scandal/. Accessed 7 January 2020.

Fosso Wamba, S., Akter, S., Edwards, A., Chopin, G., \& Gnanzou, D. (2015). How 'big Bata' can make big impact: Findings from a systematic review and a longitudinal case study. International Journal of Production Economics, 165, 234-246. https://doi.org/10.1016/j. ijpe.2014.12.031. 
Foster, I., Ghani, R., Jarmin, R. S., Kreuter, F., \& Lane, J. (Eds.). (2016). Big data and social science: : A practical guide to methods and tools. CRC Press. http://www.myilibrary.com?id=950162. Accessed 16 June 2020.

*Franceschi-Bicchierai, L., Maiberg, E., \& Koebler, J. (2018). Why We're Not Calling the Cambridge Analytica Story a "Data Breach." Motherboard. https://motherboard.vice.com/en_us/article/ 3kjzvk/facebook-cambridge-analytica-not-a-data-breach. Accessed 16 August 2018.

Fredriksson, C. (2018). Big data creating new knowledge as support in decision-making: Practical examples of big data use and consequences of using big data as decision support. Journal of Decision Systems, 27(1), 1-18. https://doi.org/10.1080/12460125.2018. 1459068.

Geissinger, A., Laurell, C., \& Sandström, C. (2020). Digital disruption beyond Uber and Airbnb-Tracking the long tail of the sharing economy. Technological Forecasting and Social Change, 155, 119323. https://doi.org/10.1016/j.techfore.2018.06.012.

George, G., Haas, M. R., \& Pentland, A. (2014). Big Data and Management. Academy of Management Journal, 57(2), 321-326. https://doi.org/10.5465/amj.2014.4002.

Ginsberg, J., Mohebbi, M. H., Patel, R. S., Brammer, L., Smolinski, M. S., \& Brilliant, L. (2009). Detecting influenza epidemics using search engine query data. Nature, 457(7232), 1012-1014. https:// doi.org/10.1038/nature07634.

Gollnhofer, J. F. (2017). The legitimation of a sustainable practice through dialectical adaptation in the marketplace. Journal of Public Policy \& Marketing, 36(1), 156-168. https://doi.org/10. 1509/jppm.15.090.

Gupta, A., Deokar, A., Iyer, L., Sharda, R., \& Schrader, D. (2018). Big Data \& Analytics for societal impact: Recent research and trends. Information Systems Frontiers, 20(2), 185-194. https://doi.org/10. 1007/s10796-018-9846-7.

Gupta, M., \& George, J. F. (2016). Toward the development of a big data analytics capability. Information \& Management, 53(8), 10491064. https://doi.org/10.1016/j.im.2016.07.004.

*Gupte, M. (2018). Consent, privacy and data usage code: Here's what Sam Balsara, Falguni Nayar have to say. The Economic Times. https://economictimes.indiatimes.com/magazines/panache/consentprivacy-and-data-usage-code-heres-what-sam-balsara-falguninayar-have-to-say/articleshow/63919238.cms

Guttentag, D. (2015). Airbnb: Disruptive innovation and the rise of an informal tourism accommodation sector. Current Issues in Tourism, 18(12), 1192-1217. https://doi.org/10.1080/13683500.2013. 827159 .

Haack, P., Pfarrer, M. D., \& Scherer, A. G. (2014). Legitimacy-as-feeling: How affect leads to vertical legitimacy spillovers in transnational governance: Legitimacy-as-feeling. Journal of Management Studies, 51(4), 634-666. https://doi.org/10.1111/joms.12071.

Hamari, J., Sjöklint, M., \& Ukkonen, A. (2016). The sharing economy: Why people participate in collaborative consumption. Journal of the Association for Information Science and Technology, 67(9), 20472059. https://doi.org/10.1002/asi.23552.

Hartley, J. H. (1994). Case Studies in Organisational Research. In C. Cassell \& G. Symon (Eds.), Qualitative methods in organizational research: a practical guide (pp. 202-229). London ; Thousand Oaks, Calif: Sage Publications.

*Hatmaker, T. (2018). A new study of Airbnb paints an ugly picture of the company's impact on New York City housing. TechCrunch. http://social.techcrunch.com/2018/01/31/nyc-new-york-airbnbstudy-mcgill/. Accessed 13 August 2018.

*Hempel, J. (2018). Airbnb Can't win New York-But it Can't quit either. Wired. https://www.wired.com/story/airbnb-cant-win-newyorkbut-it-cant-quit-either/. Accessed 15 August 2018.

*Hern, A. (2019). Cambridge Analytica did work for leave. EU, emails show. The Guardian. https://www.theguardian.com/uk-news/2019/ jul/30/cambridge-analytica-did-work-for-leave-eu-emails-confirm. Accessed 7 January 2020.

*Hickey, S., \& Cookney, F. (2016). Airbnb faces worldwide opposition. It plans a movement to rise up in its defence. The Observer. https:// www.theguardian.com/technology/2016/oct/29/airbnb-backlashcustomers-fight-back-london. Accessed 14 January 2020.

*Hinsliff, G. (2018). Airbnb and the so-called sharing economy is hollowing out our cities | Gaby Hinsliff. The Guardian. https:// www.theguardian.com/commentisfree/2018/aug/31/airbnb-sharingeconomy-cities-barcelona-inequality-locals. Accessed 6 January 2020.

*Hoggins, T. (2019). TfL should have come down harder on Uber - it's just kicking the can down the road. The Telegraph. https://www. telegraph.co.uk/technology/2019/09/24/tfl-should-have-comeharder-uber-just-kicking-can-road/. Accessed 17 June 2020.

*Holder, S. (2019). This Uber driver started a legal Battle that could upend the gig economy. Bloomberg.com. https://www.bloomberg. com/news/articles/2019-08-22/why-uber-drivers-are-fighting-fortheir-data. Accessed 25 February 2021.

Hsieh, H.-F., \& Shannon, S. E. (2005). Three approaches to qualitative content analysis. Qualitative Health Research, 15(9), 1277-1288. https://doi.org/10.1177/1049732305276687.

Huang, S.-C., McIntosh, S., Sobolevsky, S., \& Hung, P. C. K. (2017). Big data analytics and business intelligence in industry. Information Systems Frontiers, 19(6), 1229-1232. https://doi.org/10.1007/ s10796-017-9804-9.

Hwang, J. (2019). Managing the innovation legitimacy of the sharing economy. International Journal of Quality Innovation, 5(1), 1. https://doi.org/10.1186/s40887-018-0026-0.

*Isaac, M. (2019). How Uber Got Lost. The New York Times. https:// www.nytimes.com/2019/08/23/business/how-uber-got-lost.html. Accessed 17 June 2020

Janssen, M., van der Voort, H., \& Wahyudi, A. (2017). Factors influencing big data decision-making quality. Journal of Business Research, 70, 338-345. https://doi.org/10.1016/j.jbusres.2016.08.007.

*Jenkins, P. (2018). What impact will the Facebook scandal have? https:// www.ft.com/content/666d50ae-47dd-11e8-8ae9-4b5ddcca99b3

Jonsen, K., \& Jehn, K. A. (2009). Using triangulation to validate themes in qualitative studies. Qualitative Research in Organizations and Management: An International Journal, 4(2), 123-150. https://doi. org/10.1108/17465640910978391.

Keevers, T. L. (2019). Cross-validation is insufficient for model validation. Fisherman's bend, Victoria, Australia: Defence Science and Technology Group. https://www.dst.defence.gov.au/sites/default/ files/publications/documents/DST-Group-TR-3576.pdf

*Keighran, D. (2018). Up in the Airbnb. Monday Business Briefing. https://www.mondaq.com/australia/hotels-hospitality/679148/upin-the-airbnb

Kilkki, K., Mäntylä, M., Karhu, K., Hämmäinen, H., \& Ailisto, H. (2018). A disruption framework. Technological Forecasting and Social Change, 129, 275-284. https://doi.org/10.1016/j.techfore. 2017.09.034.

Krippendorff, K. (2004). Reliability in content analysis: Some common misconceptions and recommendations. Human Communication Research, 30(3), 411-433. https://doi.org/10.1111/j.1468-2958. 2004.tb00738.x.

Lasi, H., Fettke, P., Kemper, H.-G., Feld, T., \& Hoffmann, M. (2014). Industry 4.0. Business \& Information Systems Engineering, 6(4), 239-242. https://doi.org/10.1007/s12599-014-0334-4.

*Lazer, D., \& Kennedy, R. (2015). What We Can Learn From the Epic Failure of Google Flu Trends. Wired. https://www.wired.com/2015/ 10/can-learn-epic-failure-google-flu-trends/. Accessed 16 August 2018.

*Lazer, D., Kennedy, R., King, G., \& Vespignani, A. (2014). The parable of Google flu: Traps in big data analysis. Science, 343(6176), 1203 1205. https://doi.org/10.1126/science.1248506. 
*Lee, P. (2019). How Facebook can win the global currency battle. Euromoney. https://www.euromoney.com/article/b1gxhl2n851rlw/ how-facebook-can-win-the-global-currency-battle. Accessed 17 June 2020.

*Levin, S. (2017). Uber's scandals, blunders and PR disasters: The full list. The Guardian. https:/www.theguardian.com/technology/2017/ jun/18/uber-travis-kalanick-scandal-pr-disaster-timeline. Accessed 17 June 2020.

*Lewis, P., \& Hilder, P. (2018). Leaked: Cambridge Analytica's blueprint for Trump victory. The Guardian. https:/www.theguardian. com/uk-news/2018/mar/23/leaked-cambridge-analyticas-blueprintfor-trump-victory. Accessed 7 January 2020.

Lillqvist, E., Moisander, J., \& Firat, F. (2017). Consumers as legitimating agents: How consumer-citizens challenge marketer legitimacy on social media. International Journal of Consumer Studies., 42, 197-204. https://doi.org/10.1111/ijcs.12401.

Lischka, J. A. (2019). Strategic communication as discursive institutional work: A critical discourse analysis of mark Zuckerberg's legitimacy talk at the European Parliament. International Journal of Strategic Communication, 13(3), 197-213. https://doi.org/10.1080/ 1553118X.2019.1613661.

Lozano, M. G., Brynielsson, J., Franke, U., Rosell, M., Tjörnhammar, E., Varga, S., \& Vlassov, V. (2020). Veracity assessment of online data. Decision Support Systems, 129, 113132. https://doi.org/10.1016/j. dss.2019.113132.

*Lytvynenko, J. (2020). In 2020, Disinformation Broke The US. BuzzFeed News. https://www.buzzfeednews.com/article/ janelytvynenko/disinformation-broke-us. Accessed 12 January 2021.

*Madrigal, A. C. (2014). In Defense of Google Flu Trends. The Atlantic. https://www.theatlantic.com/technology/archive/2014/03/indefense-of-google-flu-trends/359688/. Accessed 17 June 2020.

Marr, B. (2015). The 5 V's of big data. Data Science Central. https:// www.datasciencecentral.com/profiles/blogs/the-5-v-s-of-big-databy-bernard-marr. Accessed 16 June 2020.

*Martineau, P. (2019). Inside Airbnb's "guerrilla war" against local governments. Wired. https://www.wired.com/story/inside-airbnbsguerrilla-war-against-local-governments/. Accessed 24 February 2021.

Mayring, P. (2000). Qualitative content analysis. Forum Qualitative Sozialforschung, 1(2). https://www.psychopen.eu/fileadmin/user upload/books/mayring/ssoar-2014-mayring-Qualitative content analysis_theoretical_foundation.pdf

*McCarthy, J. (2018). People aren't deleting Facebook after Cambridge Analytica scandal though trust is at a low. The Drum. https://www. thedrum.com/news/2018/04/25/people-arent-deleting-facebookafter-cambridge-analytica-scandal-though-trust-low. Accessed 7 January 2020.

McCutcheon, D. M., \& Meredith, J. R. (1993). Conducting case study research in operations management. Journal of Operations Management, 11(3), 239-256. https://doi.org/10.1016/02726963(93)90002-7.

Merendino, A., Dibb, S., Meadows, M., Quinn, L., Wilson, D., Simkin, L., \& Canhoto, A. (2018). Big data, big decisions: The impact of big data on board level decision-making. Journal of Business Research, 93, 67-78. https://doi.org/10.1016/j.jbusres.2018.08.029.

Millar, C., Lockett, M., \& Ladd, T. (2018). Disruption: Technology, innovation and society. Technological Forecasting and Social Change, 129, 254-260. https://doi.org/10.1016/j.techfore.2017.10. 020.

*Murgia, M. (2017). Is Uber a transport company or internet service? https://www.ft.com/content/1a8f6c0e-363a-11e7-bce49023f8c0fd2e. Accessed 24 February 2021.

*Newcomer, E., \& Rosenblatt, J. (2019). Here's the Uber investor letter that forced Travis Kalanick out. Bloomberg.com. https://www. bloomberg.com/news/articles/2019-01-28/here-s-the-uber-investorletter-that-forced-travis-kalanick-out. Accessed 7 January 2020.

Newman, D. (2014). Big Data Means Big Disruption. Forbes. https:// www.forbes.com/sites/danielnewman/2014/06/03/big-data-meansbig-disruption/. Accessed 23 February 2021.

*NYC-OSE. (n.d.). About Illegal Short-Term Rentals - OSE. https:// www1.nyc.gov/site/specialenforcement/stay-in-the-know/aboutillegal-short-term-rentals.page. Accessed 6 January 2020.

*O'Connor, S. (2017). Driven to despair - The hidden costs of the gig economy. Financial Times. https://www.ft.com/content/749cb87e6ca8-11e7-b9c7-15af748b60d0. Accessed 13 August 2018.

OECD. (2015). Data-driven Innovation: Big Data for Growth and WellBeing. OECD. https://doi.org/10.1787/9789264229358-en.

O'Neil, C. (2016). Weapons of math destruction: How big data increases inequality and threatens democracy. Crown.

Opresnik, D., \& Taisch, M. (2015). The value of big data in servitization. International Journal of Production Economics, 165, 174-184. https://doi.org/10.1016/j.ijpe.2014.12.036.

*Osborne, H. (2018). What is Cambridge Analytica? The firm at the Centre of Facebook's data breach. The Guardian. https://www. theguardian.com/news/2018/mar/18/what-is-cambridge-analyticafirm-at-centre-of-facebook-data-breach. Accessed 7 January 2020.

*O'Shea, L. (2018). Tech has no moral code. It is everyone's job now to fight for one | Lizzie O'Shea. The Guardian. https://www. theguardian.com/commentisfree/2018/apr/25/tech-no-moral-coderacist-ads-cambridge-analytica-technology-ethical-deficit. Accessed 17 June 2020.

Pappas, I. O., Mikalef, P., Giannakos, M. N., Krogstie, J., \& Lekakos, G. (2018). Big data and business analytics ecosystems: Paving the way towards digital transformation and sustainable societies. Information Systems and e-Business Management, 16(3), 479-491. https://doi. org/10.1007/s10257-018-0377-z.

*Parkinson, H. J. (2017). 'Sometimes you don't feel human' - How the gig economy chews up and spits out millennials. The Guardian. https://www.theguardian.com/business/2017/oct/17/sometimesyou-dont-feel-human-how-the-gig-economy-chews-up-and-spitsout-millennials. Accessed 13 August 2018.

Patala, S., Korpivaara, I., Jalkala, A., Kuitunen, A., \& Soppe, B. (2019). Legitimacy under institutional change: How incumbents appropriate clean rhetoric for dirty technologies. Organization Studies, 40(3), 395-419. https://doi.org/10.1177/0170840617736938.

Patton, M. Q. (2002). Two decades of developments in qualitative inquiry: A personal, experiential perspective. Qualitative Social Work: Research and Practice, 1(3), 261-283. https://doi.org/10.1177/ 1473325002001003636.

*Perriello, T. (2019). Don't worry about China when breaking up Facebook. TheHill. Text. https://thehill.com/blogs/congress-blog/ politics/448834-dont-worry-about-china-when-breaking-upfacebook. Accessed 7 January 2020.

Popovič, A., Hackney, R., Tassabehji, R., \& Castelli, M. (2018). The impact of big data analytics on firms' high value business performance. Information Systems Frontiers, 20(2), 209-222. https://doi. org/10.1007/s10796-016-9720-4.

Prescott, M. E. (2016). Big data: Innovation and competitive advantage in an information media analytics company. Journal of Innovation Management, 4(1), 92-113. https://doi.org/10.24840/2183-0606_ 004.0010007.

*Rahman, K. S. (2018). The new octopus. Logic Magazine. https:// logicmag.io/scale/the-new-octopus/. Accessed 7 January 2020.

*Ram, A., \& O'Connor, S. (2017). Uber loses appeal in UK employment case. Financial Times. https://www.ft.com/content/84de88bc-c5ee11e7-a1d2-6786f39ef675. Accessed 15 August 2018.

*Romano, A. (2018). The Facebook data breach wasn't a hack. It was a wake-up call. Vox. https://www.vox.com/2018/3/20/17138756/ facebook-data-breach-cambridge-analytica-explained. Accessed 16 August 2018. 
*RT. (2014). Google Flu Trends: Grossly misleading or misunderstood science? RT International. https://www.rt.com/news/google-flutrends-science-105/. Accessed 7 January 2020.

*Russon, M.-A. (2021). UK Supreme Court rules Uber drivers are workers. BBC News. https://www.bbc.com/news/business56123668. Accessed 19 February 2021.

*Salzberg, S. (2014). Why Google Flu Is A Failure. Forbes. https://www. forbes.com/sites/stevensalzberg/2014/03/23/why-google-flu-is-afailure/. Accessed 17 June 2020.

*Satariano, A. (2018). Uber claims to have changed. A London Judge Will Decide. - The New York Times. NYTimes. https://www. nytimes.com/2018/06/24/technology/uber-london-appeal.html. Accessed 27 June 2018.

Schembera, S., \& Scherer, A. G. (2017). Organizational strategies in the context of legitimacy loss: Radical versus gradual responses to disclosed corruption. Strategic Organization, 15(3), 301-337. https://doi.org/10.1177/1476127016685237.

Schumpeter, J. A. (1942). Capitalism, socialism and democracy. Routledge. Accessed 8 January 2011.

Scott, W. R. (2014). Institutions and organizations: Ideas, interests, and identities (Fourth ed.). SAGE.

*Sherr, I. (2018). Facebook, Cambridge Analytica, data mining and trump: What you need to know. CNET. https:/www.cnet.com/ news/facebook-cambridge-analytica-data-mining-and-trump-whatyou-need-to-know/. Accessed 16 August 2018.

*Sherwood, H. (2019). How Airbnb took over the world. The Guardian. https://www.theguardian.com/technology/2019/may/05/airbnbhomelessness-renting-housing-accommodation-social-policy-citiestravel-leisure. Accessed 6 January 2020.

*Simmons, A. (2019). Short-term rental Laws in major U.S. cities (updated 12/10/2019). 2nd Address Research. https://www.2ndaddress. com/research/short-term-rental-laws/. Accessed 7 January 2020.

*Solon, O. (2018a). WhatsApp co-founder joins call to \#DeleteFacebook as fallout intensifies. The Guardian. https://www.theguardian.com/ technology/2018/mar/20/facebook-cambridge-analytica-whatsappdelete. Accessed 7 January 2020.

*Solon, O. (2018b). Teens are abandoning Facebook in dramatic numbers, study finds. The Guardian. https://www.theguardian.com/ technology/2018/jun/01/facebook-teens-leaving-instagramsnapchat-study-user-numbers. Accessed 7 January 2020.

*Solon, O., \& Laughland, O. (2018). Cambridge Analytica closing after Facebook data harvesting scandal. The Guardian. https://www. theguardian.com/uk-news/2018/may/02/cambridge-analyticaclosing-down-after-facebook-row-reports-say. Accessed 16 August 2018.

*Spinks, R. (2018). Spain is cracking down hard on Airbnb, just in time for tourist season. Quartzy. https://qz.com/quartzy/1276970/airbnbin-spain-madrids-new-rules-on-home-sharing-follow-tough-rulesin-valencia-and-palma/. Accessed 15 August 2018.

Stahl, B. C., McBride, N., Wakunuma, K., \& Flick, C. (2014). The empathic care robot: A prototype of responsible research and innovation. Technological Forecasting and Social Change, 84, 74-85. https://doi.org/10.1016/j.techfore.2013.08.001.

Stake, R. E. (1995). The art of case study research. SAGE Publications Ltd.

Suchman, M. C. (1995). Managing legitimacy: Strategic and institutional approaches. The Academy of Management Review, 20(3), 571. https://doi.org/10.2307/258788.

Suddaby, R., Bitektine, A., \& Haack, P. (2017). Legitimacy. Academy of Management Annals, 11(1), 451-478. https://doi.org/10.5465/ annals.2015.0101.

Tan, K. H. (2018). Managerial perspectives of big data analytics capability towards product innovation. Strategic Direction, 34(8), 33-35. https://doi.org/10.1108/SD-06-2018-0134.

*Temperton, J. (2018). The biggest legal crisis facing Uber started with a pile of vomit. Wired UK. https://www.wired.co.uk/article/uber- employment-lawsuit-gig-economy-leigh-day. Accessed 15 August 2018.

*TfL. (2019). Uber London limited found to be not fit and proper to hold a private hire operator licence. Transport for London. https:/ttfl.gov. uk. Accessed 17 June 2020.

*Thompson, N. (2019). 15 months of fresh hell inside Facebook. Wired. https://www.wired.com/story/facebook-mark-zuckerberg-15months-of-fresh-hell/. Accessed 7 January 2020.

*Thomson, A., Lanxon, N., \& Bloomberg. (2019). Uber's London Ban: The Beginning of a Global Ride-Hailing Backlash? Fortune. https:// fortune.com/2019/11/27/uber-london-ban-global-ride-hailingbacklash/. Accessed 7 January 2020.

*Ting, D. (2017). Airbnb Tries to Clear Away Political and Legal Challenges in New York and San Francisco. Skift. https://skift. com/2017/05/01/airbnb-tries-to-clear-away-political-and-legalchallenges-in-new-york-and-san-francisco/. Accessed 15 August 2018

Tolbert, P. S., \& Zucker, L. G. (1983). Institutional sources of change in the formal structure of organizations: The diffusion of civil service reform, 1880-1935. Administrative Science Quarterly, 28(1), 22. https://doi.org/10.2307/2392383.

*Topham, G. (2019). Uber loses London licence after TfL finds drivers faked identity. The Guardian. https://www.theguardian.com/ technology/2019/nov/25/uber-loses-licence-london-tfl. Accessed 17 June 2020

Tost, L. P. (2011). An integrative model of legitimacy judgments. Academy of Management Review, 36(4), 686-710. https://doi.org/ 10.5465/amr.2010.0227.

*Tufekci, Z. (2018). Opinion | Facebook's surveillance machine. The New York Times. https://www.nytimes.com/2018/03/19/opinion/ facebook-cambridge-analytica.html. Accessed 16 August 2018.

*Valdez, A. (2018). Everything You Need to Know About Facebook and Cambridge Analytica. Wired. https://www.wired.com/story/wiredfacebook-cambridge-analytica-coverage/. Accessed 16 August 2018.

van den Broek, T., \& van Veenstra, A. F. (2018). Governance of big data collaborations: How to balance regulatory compliance and disruptive innovation. Technological Forecasting and Social Change, 129,330-338. https://doi.org/10.1016/j.techfore.2017.09.040.

*Vincent, M. (2018). GSK's $\$ 300 \mathrm{~m}$ genetic testing deal shows changes in its DNA. Financial Times.

*Wachsmuth, D., Chaney, D., Kerrigan, D., Shillolo, A., \& BasalaevBinder, R. (2018). The high cost of short-term rentals in new York City. Montreal: McGill University. https://mcgill.ca/newsroom/ files/newsroom/channels/attach/airbnb-report.pdf

*Wachsmuth, D., \& Weisler, A. (2018). Airbnb and the rent gap: Gentrification through the sharing economy. Environment and Planning A: Economy and Space, 50(6), 1147-1170. https://doi. org/10.1177/0308518X18778038.

*Ward, A. (2014). Google catches cold as debate over "big data hubris" rages. Financial Times. https://www.ft.com/content/813c5da60b61-11e4-9e55-00144feabdc0. Accessed 24 February 2021.

*Waterson, J. (2018a). British adults using Facebook less to communicate with friends. The Guardian. https://www.theguardian.com/ technology/2018/apr/25/british-adults-using-facebook-less-tocommunicate-with-friends. Accessed 7 January 2020.

*Webster, T. (2019). Unfriending Facebook: New Research On Why People Like Facebook Less. Medium. https://medium.com/swlh/ unfriending-facebook-new-research-on-why-people-like-facebookless-74894b927a0. Accessed 7 January 2020.

*Wessel, M. (2016). How Big Data Is Changing Disruptive Innovation. Harvard Business Review. https://hbr.org/2016/01/how-big-data-ischanging-disruptive-innovation. Accessed 16 June 2020.

*White, J. B. (2018a). Cambridge Analytica is shutting down following Facebook user data scandal | The Independent. https://www. independent.co.uk/life-style/gadgets-and-tech/news/cambridge- 
analytica-shutting-down-closing-uk-us-facebook-data-scandalcontroversy-a8333496.html. Accessed 7 January 2020.

*White, J. B. (2018b ). The Cambridge Analytica scandal has hit Facebook's stock value hard. The Independent. https://www. independent.co.uk/news/business/news/facebook-stock-marketvalue-cambridge-analytica-data-breach-a8264251.html. Accessed 20 August 2018.

Wilson, A., Thompson, T. L., Watson, C., Drew, V., \& Doyle, S. (2017). Big data and learning analytics: Singular or plural? First Monday, 22(4). https://doi.org/10.5210/fm.v22i4.6872.

Witt, A., Suzor, N., \& Wikström, P. (2015). Regulating ride-sharing in the peer economy. Communication Research and Practice, 1(2), 174-190. https://doi.org/10.1080/22041451.2015.1048041.

*Wong, J. C. (2018). Mark Zuckerberg apologises for Facebook's "mistakes" over Cambridge Analytica. The Guardian. https:/www. theguardian.com/technology/2018/mar/21/mark-zuckerbergresponse-facebook-cambridge-analytica. Accessed 7 January 2020.

*Yakabuski, K. (2014). Big data's noise is drowning out the signal. The Globe and Mail. https://www.theglobeandmail.com/opinion/bigdatas-noise-is-drowning-out-the-signal/article18458939/. Accessed 17 June 2020.

Yin, R. K. (2009). Case study research (4th ed.). Sage Publications, Inc..

*Zadeh, A. H., Zolbanin, H. M., Sharda, R., \& Delen, D. (2019). Social Media for Nowcasting flu Activity: Spatio-temporal big data analysis. Information Systems Frontiers, 21(4), 743-760. https://doi.org/ 10.1007/s10796-018-9893-0.

Zhan, Y., Tan, K. H., Ji, G., Chung, L., \& Tseng, M. (2017). A big data framework for facilitating product innovation processes. Business Process Management Journal, 23(3), 518-536. https://doi.org/10. 1108/BPMJ-11-2015-0157.

Zhang, Y., \& Wildemuth, B. M. (2009). Qualitative analysis of content. In B. M. Wildemuth (Ed.), Applications of social research methods to questions in information and library science (pp. 1-12). Libraries Unlimited.

Zillner, S., Becker, T., Munné, R., Hussain, K., Rusitschka, S., Lippell, H., Curry, E., \& Ojo, A. (2016). Big data-driven innovation in industrial sectors. In J. M. Cavanillas, E. Curry, \& W. Wahlster (Eds.), New horizons for a data-driven economy (pp. 169-178). Springer International Publishing. https://doi.org/10.1007/978-3-319-215693.9.

Zimmerman, M. A., \& Zeitz, G. J. (2002). Beyond Survival: Achieving New Venture Growth by Building Legitimacy. Academy of
Management Review, 27(3), 414-431. https://doi.org/10.5465/amr. 2002.7389921 .

Zuboff, S. (2015). Big other: Surveillance capitalism and the prospects of an information civilization. Journal of Information Technology, 30(1), 75-89. https://doi.org/10.1057/jit.2015.5.

Publisher's Note Springer Nature remains neutral with regard to jurisdictional claims in published maps and institutional affiliations.

Dr Carlos Ferreira is an Assistant Professor at the Centre for Business in Society, Coventry University. Carlos' research interests focus primarily on how economies are made and changed, with an evolving interest in how alternative economic spaces and actors are imagined and constructed. Located at the intersection of business and policy, his work explores two main topics: how data and humans come together in business environments; and how moral and ethical concerns are translated into action in complex institutional environments.

Dr Alessandro Merendino is an Assistant Professor at the Centre for Business in Society at Coventry University. His research interests lie in the area of corporate governance, the board of directors, the top management team and big data in a wide range of industries. He is also a qualified chartered accountant and a member of a number of professional and academic bodies, including The Institute of Chartered Accountants in England and Wales, the British Academy of Management and the International Corporate Governance Society. He has extensive experience in different projects funded by national and international organisations.

Maureen Meadows is Professor of Strategic Management at the Centre for Business in Society at Coventry University. She is co-leader of a research cluster on 'Data, Organisations and Society', with a particular interest in strategic decision-making relating to 'big data'. With a background in mathematics and statistics, Maureen has many years' experience of working with customer data and analytics, both as a practitioner in the financial services sector and an academic. Her research interests include the use of strategy tools (e.g. scenario planning and visioning) and the implementation of projects such as relationship marketing and customer relationship management. 